\title{
Glass Beads from Kinsloe Focus Sites in Gregg, Harrison, and Rusk Counties, Texas
}

Timothy K. Perttula

Heritage Research Center, Stephen F. Austin State University

Robert Z. Selden Jr.

Heritage Research Center, Stephen F. Austin State University

Follow this and additional works at: https://scholarworks.sfasu.edu/ita

Part of the American Material Culture Commons, Archaeological Anthropology Commons, Environmental Studies Commons, Other American Studies Commons, Other Arts and Humanities Commons, Other History of Art, Architecture, and Archaeology Commons, and the United States History Commons

Tell us how this article helped you.

This Article is brought to you for free and open access by the Center for Regional Heritage Research at SFA ScholarWorks. It has been accepted for inclusion in Index of Texas Archaeology: Open Access Gray Literature from the Lone Star State by an authorized editor of SFA ScholarWorks. For more information, please contact cdsscholarworks@sfasu.edu. 
Glass Beads from Kinsloe Focus Sites in Gregg, Harrison, and Rusk Counties, Texas

\section{Creative Commons License}

\section{(c) (1) ()}

This work is licensed under a Creative Commons Attribution-NonCommercial 4.0 International License 


\title{
Glass Beads from Kinsloe Focus Sites in Gregg, Harrison, and Rusk Counties, Texas
}

\author{
Timothy K. Perttula and Robert Z. Selden, Jr.
}

\section{INTRODUCTION}

European glass beads are one of the most common artifact categories found on historic Caddo sites in the middle reaches of the Sabine River basin in East Texas on what Jones (1968) had dubbed Kinsloe focus sites. Several thousands beads were found by Jones in his investigation of burial features at these sites, along with other European trade goods and Caddo ceramic vessels, pipes, and chipped stone tools.

In Jones' (1968) description of the beads from the Kinsloe focus sites, he relied on the analytical and chronological interpretations of John Witthoft, then of the Pennsylvania Historical and Museum Commission, although he did seek the advice of R. K. Harris, a notable glass beads expert who had worked on numerous historic Caddo and Wichita sites in eastern and northern Texas. Witthoft's interpretations of the age of the beads from the sites tended to suggest that the Kinsloe focus sites dated to the early $17^{\text {th }}$ century - when beads of such types tended to date in aboriginal sites in the Northeast U.S. - while Harris suggested that the glass beads on the Kinsloe focus sites dated from no earlier than the early $18^{\text {th }}$ century, and likely dated in several cases after ca. A.D. 1750. Given the likely late $17^{\text {th }}$ to late $18^{\text {th }}$ century ages of the engraved ceramic vessels found on the Kinsloe focus sites, based in large measure on their occurrence on a wide range of Historic Caddo sites, Harris' temporal interpretations of the glass bead assemblages are consistent with these ceramic temporal ranges, and thus the Kinsloe focus sites are seen as indicative of Caddo settlements postdating the beginning of intensive contact between Europeans and Caddo peoples that began after A.D. 1685 .

\section{GLASS BEAD SAMPLES FROM KINSLOE FOCUS SITES AS DESCRIBED BY JONES}

Jones (1968) did not always consistently provide numerical details on the numbers of glass beads recovered from the seven Kinsloe focus sites in his study. Two sites were reported to have had over 2000 glass beads each, namely the Ware Acres (41GG31) and Millsey Williamson (41RK3) sites (Jones 1968:19, 64), but another tabulation indicated that he had a sample of 1986 beads from Ware Acres (Jones 1968:21), and Jones provided no specific tabulation of the number of beads he had collected at the Millsey Williamson site. Similarly, he provided no tabulation of the number of glass beads from the Kinsloe site. Jones (1968:55, $120,152)$ did indicate that in his sample of glass beads there were 15 beads from the Cherokee Lake site (41RK132), 15 beads from the Susie Slade site (41HS13), and 175 beads from the Brown Burial \#1 site (41HS261). No glass beads were collected from the C. D. Marsh site (41HS269) during Jones' work there.

\section{BEAD SAMPLES FROM GREGG COUNTY HISTORICAL MUSEUM'S BUDDY JONES COLLECTIONS}

During the course of documenting Caddo collections of ceramic vessels and other funerary offerings in the Buddy Jones collection at the Gregg County Historical Museum, we had an opportunity to analyze all of the glass beads in the Jones collection. Unfortunately, with a few exceptions, such as a single glass bead from the Henry Spencer site (41UR315) (Perttula et al. 2012:Figure 179), an oval-shaped blue bead from the Patton site (41HS825) (Perttula et al. 2013a), and a strand of 864 white, blue, and red glass beads 
from Burial 3 at the Vanderpool site (41SM77) (Perttula et al. 2013b:Figure 18), the other glass beads in the collection now have no specific provenience other than that they came from six of the seven Kinsloe focus sites. The provenience of these glass beads was lost when Jones either put the glass beads from specific sites on strands for display purposes in his family museum (without labeling or separating the beads from specific sites from each other) or laid them out as border decorative items on frames of projectile points and other chipped stone tools.

Consequently, in our analysis of the glass beads in the Jones collection, we have treated the beads as representing a single Kinsloe focus assemblage rather than the separate assemblages of the six Kinsloe focus sites known to have had glass beads. There is a total of 7926 drawn glass beads in the single unprovenienced inter-site assemblage (Table 1). Almost 58\% of the beads are white in color, but with substantial percentages of red, black, and blue glass beads. One unique bead is a yellowish-brown color.

Table 1. Color of the Beads from the Collection.

\begin{tabular}{lrc}
\hline Color & Number & Percentage \\
\hline White & 4585 & 57.7 \\
Red & 1259 & 15.9 \\
Black & 1071 & 14.8 \\
Blue & 1010 & 12.8 \\
Yellowish-brown & 1 & Trace \\
\hline Totals & 7926 & 100.0 \\
\hline
\end{tabular}

The prevalence of white glass beads in the Kinsloe focus assemblage is matched by only a few Caddo bead assemblages that date from the early 18th century to as late as ca. 1830, including Womack (41LR1, 64\%), Roseborough Lake (41BW5, 48\%), and Ware Acres (41GG31, 46\%, following Jones' [1968:21] original tabulation) (Avery 2008:Table 1). Red beads, primarily Cornaline d'Aleppo multi-layered beads with a red outer layer and a dark gray or black core, are also important components of several other Caddo bead assemblages, such as at the Gilbert site (41RA13, 13\%), Deshazo (41NA27, 10\%), Ware Acres (36\%), and Colfax Ferry $(16 \mathrm{NA} 15,11 \%)$. Black beads that occur in Caddo sites in comparable proportions to the Kinsloe focus bead sample are noted only at Gilbert (13\%) and Ware Acres (Avery 2008:Table 1), while generally comparable percentages of Caddo sites with blue beads occur only at Spradley (41NA206, 29\%) (Avery 2008:Table 1). Other Caddo sites with large assemblages of beads listed by Avery (2008:Table 1) tend to have much higher proportions of blue glass beads (ranging from 32-98\%), which suggests that the Caddo peoples represented by the Kinsloe focus, namely the Nadaco Caddo (Fields and Gadus 2012; Jones 1968), had distinctly different color preferences for beads than did other East Texas or Northwest Louisiana Caddo groups.

Approximately 99\% of the glass beads from the Kinsloe focus sites are small in size (2-4 mm) (Table 2), and can be classified as seed beads that were likely to have been sown onto clothing, such as beaded shirts or other beaded clothing styles (Perttula 1992:217). Slightly larger beads (4-10 $\mathrm{mm}$ in size) were probably worn as necklaces and bracelets.

Following the distinctions made by Kidd and Kidd $(1970: 50,53)$ between glass beads, approximately $97 \%$ of the Kinsloe focus beads are rounded, with one or multiple layers of different colors of glass (Table 3). These are tubular beads "that have been subjected to rounding by reheating" and tumbling (Kidd and Kidd 1970:53). The remainder of the Kinsloe focus glass beads are tubular (3\%), with one or more layers of glass, where tubes of glass are "broken up into short lengths, and these are finally chopped into sizes which will serve as beads" (Kidd and Kidd 1970:49). Multi-layered glass beads comprise 15.8\% of the glass bead assemblage, almost all as rounded beads rather than tubular. 
Table 2. Size of the Beads from the Collection.

\begin{tabular}{lrc}
\hline Size & Number & Percentage \\
\hline Small $(2-4 \mathrm{~mm})$ & 7847 & 99.0 \\
Medium $(4-6 \mathrm{~mm})$ & 48 & 0.6 \\
Large $(6-10 \mathrm{~mm})$ & 31 & 0.4 \\
\hline Totals & 7926 & 100.0 \\
\hline
\end{tabular}

Table 3. Bead Classes from the Collection.

\begin{tabular}{lrc}
\hline Class & Number & Percentage \\
\hline Tubular & 241 & 3.0 \\
Tubular, Multi-Layered & 2 & Trace \\
Rounded & 6425 & 81.2 \\
Rounded, Multi-Layered & 1257 & 15.8 \\
Rounded, with Stripes & 1 & Trace \\
\hline Totals & 7926 & 100.0 \\
\hline
\end{tabular}

In sorting through the Kinsloe focus glass bead assemblage, we relied on color, number of layers, shape, and size (i.e., diameter and/or length) differences to define 36 different bead groups (Table 4). Subsequent analyses has led to the collapsing of some of these groups into 32 larger bead groupings (Figure 1-30). Of the 32 groups in the Kinsloe focus glass beads, the five principal bead groups include Group 34 (Figure $30,45.6 \%$ of all the beads), Group 28 (Figure 24, 15.9\%), Group 35 (10.3\%), Group 25/26 (Figure 22a-b, $10.0 \%$ ), and Group 31 (Figure 27, 8.3\%). These represent, respectively, small round white beads; small round red over black Cornaline d'Aleppo beads; small round white seed beads; small round blue beads; and small round black beads.

Table 4. Bead groups defined in the assemblage.

\begin{tabular}{llrl}
\hline Group & Description & $\mathrm{N}$ & $\%$ \\
\hline 1 & White, large, round, 7.12 mm in diameter & 1 & Trace \\
2 & Yellowish-brown, large, round, $6.95 \mathrm{~mm}$ in diameter & 1 & Trace \\
3 & Aquamarine, small, round, $3.95 \mathrm{~mm}$ in diameter & 62 & 0.8 \\
$4 / 5$ & Aquamarine, small, tubular, 3.0-3.6 mm in diameter & 14 & 0.2 \\
6 & Blue, medium, round, 5.04 mm in diameter & 3 & Trace \\
7 & Blue, large, round, 8.01 mm in diameter & 1 & Trace \\
$8 / 9$ & White, large, oval, 7.59-7.62 mm in diameter & 12 & 0.2 \\
$10 / 12$ & White, large, tubular, 6.28-6.43 mm in diameter & 2 & Trace \\
11 & White, medium, round, 5.64 mm in diameter & 1 & Trace \\
13 & Aquamarine, large, round, $6.77 \mathrm{~mm}$ in diameter & 3 & Trace \\
14 & White with black surface, small, round, 3.66 mm & 3 & Trace \\
& in diameter & &
\end{tabular}


Table 4. Bead groups defined in the assemblage, cont.

\begin{tabular}{llrl}
\hline Group & Description & $\mathrm{N}$ & $\%$ \\
\hline 15 & Cornaline d'Aleppo, red with black core, medium, & 2 & Trace \\
& tubular, 4.03 mm in diameter & 1 & Trace \\
16 & Blue, large, oval, 6.81 mm in diameter & 7 & 0.1 \\
17 & Blue, large, tubular, 6.75 mm in diameter & 3 & Trace \\
18 & Blue, large, round, 7.50 mm in diameter & 2 & Trace \\
19 & Blue, medium, round, 5.43 mm in diameter & 29 & 0.4 \\
20 & Aquamarine, small, round, 2.66 mm in diameter & 1 & Trace \\
21 & White with four black stripes, medium, round, & & \\
& 5.45 mm in diameter & 1 & Trace \\
22 & Blue, small, tubular, 3.13 mm in diameter & 40 & 0.2 \\
23 & Blue, translucent, small, tubular, 2.68 mm in diameter & 795 & 0.5 \\
24 & Blue, small, round, 2.46 mm in diameter & 32 & 10.0 \\
$25 / 26$ & Blue, small, round, 3.79-3.97 mm in diameter & 1257 & 0.4 \\
27 & Blue, translucent, small, 3.52 mm in diameter & & 15.9 \\
28 & Cornaline d'Aleppo, red with black core, small, & 37 & \\
& round, 3.19 mm in diameter & 35 & 0.5 \\
29 & Black, medium, round, $4.42 \mathrm{~mm}$ in diameter & 658 & 0.4 \\
30 & Black, small, tubular, 2.63 mm in diameter & 133 & 8.3 \\
31 & Black, small, round, 3.20 mm in diameter & 2 & 1.7 \\
32 & White, small, tubular, 3.07 mm in diameter & 3612 & Trace \\
33 & White, medium, round, $4.70 \mathrm{~mm}$ in diameter & 818 & 45.6 \\
34 & White, small, round, 3.34 mm in diameter & 341 & 10.3 \\
$35^{*}$ & White, small, round, 2.48 mm in diameter & 7926 & 4.3 \\
$36 *$ & Black, small, round, 2.06-3.20 mm in diameter & 100.0 \\
\hline Totals & & & \\
\hline
\end{tabular}

*These bead groups were tabulated from beads that were mounted on artifact frames, and they consequently could not be photographed for this study

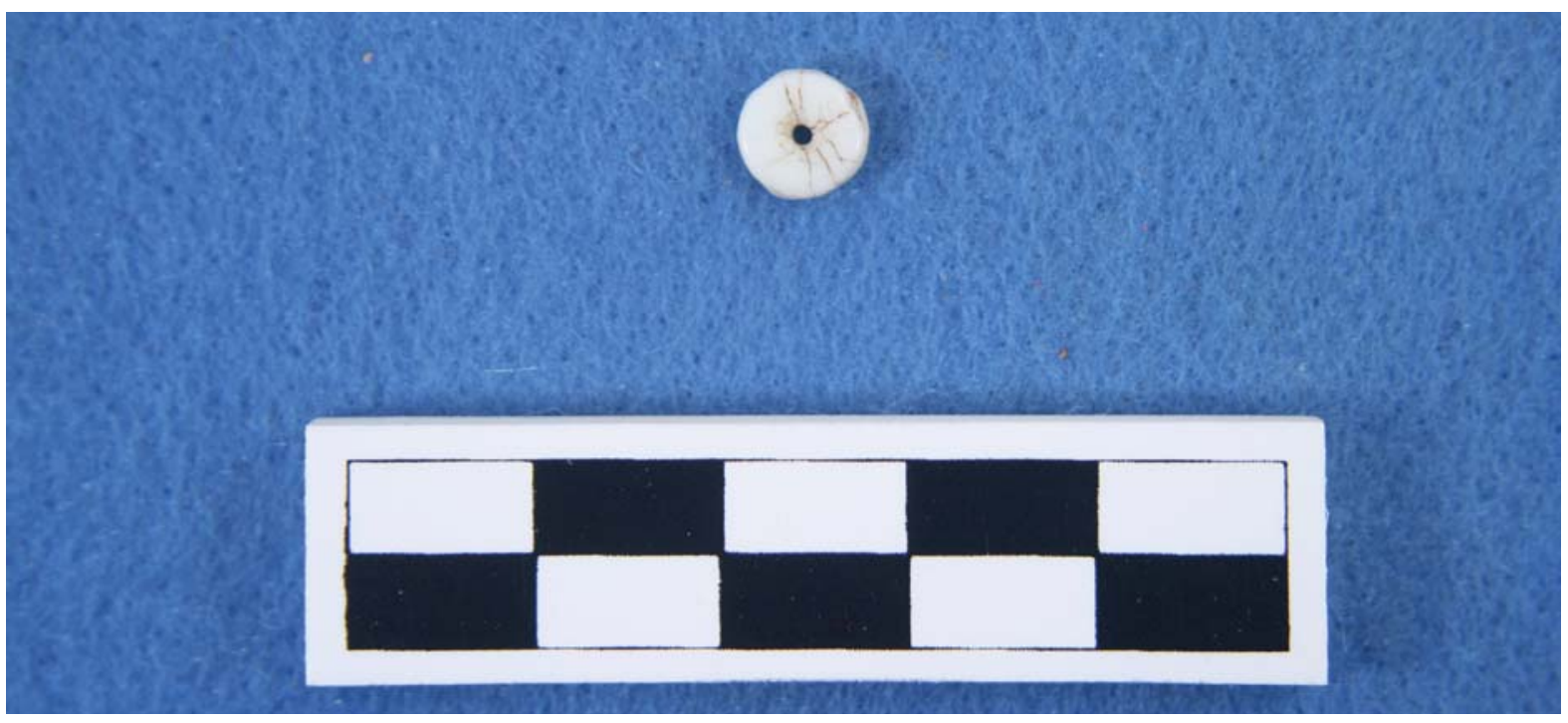

Figure 1. Glass bead group 1. 


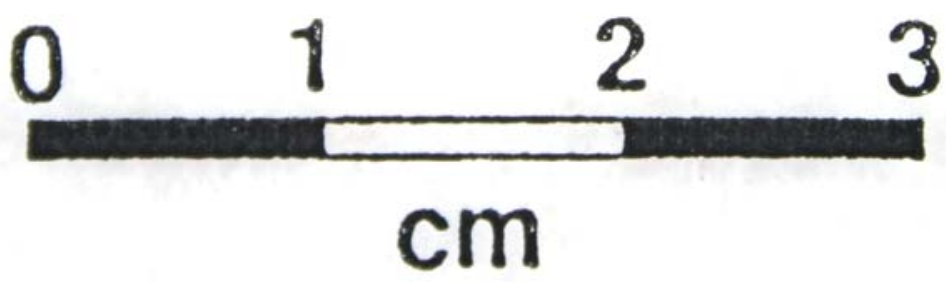

Figure 2. Glass bead group 2.
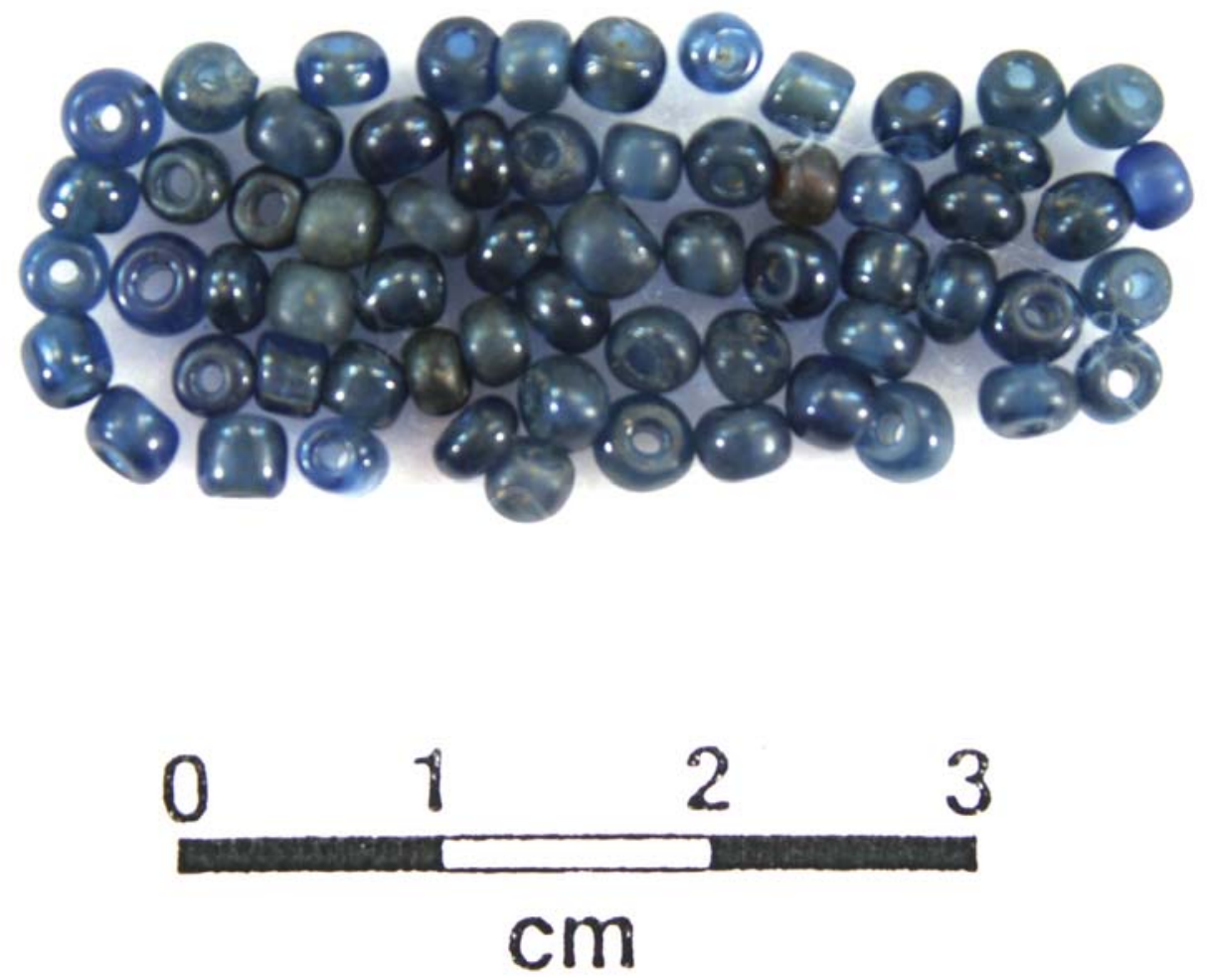

Figure 3. Glass bead group 3. 

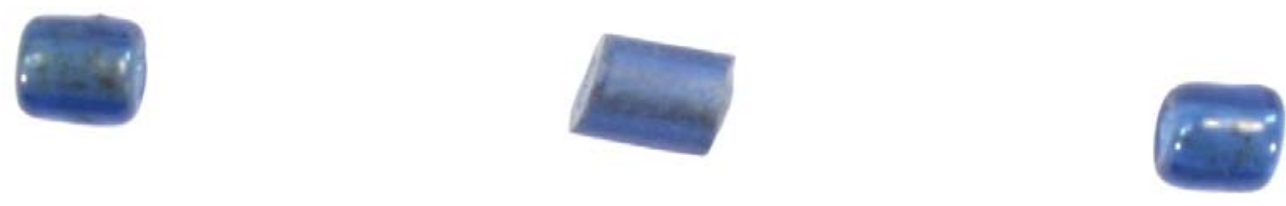

a
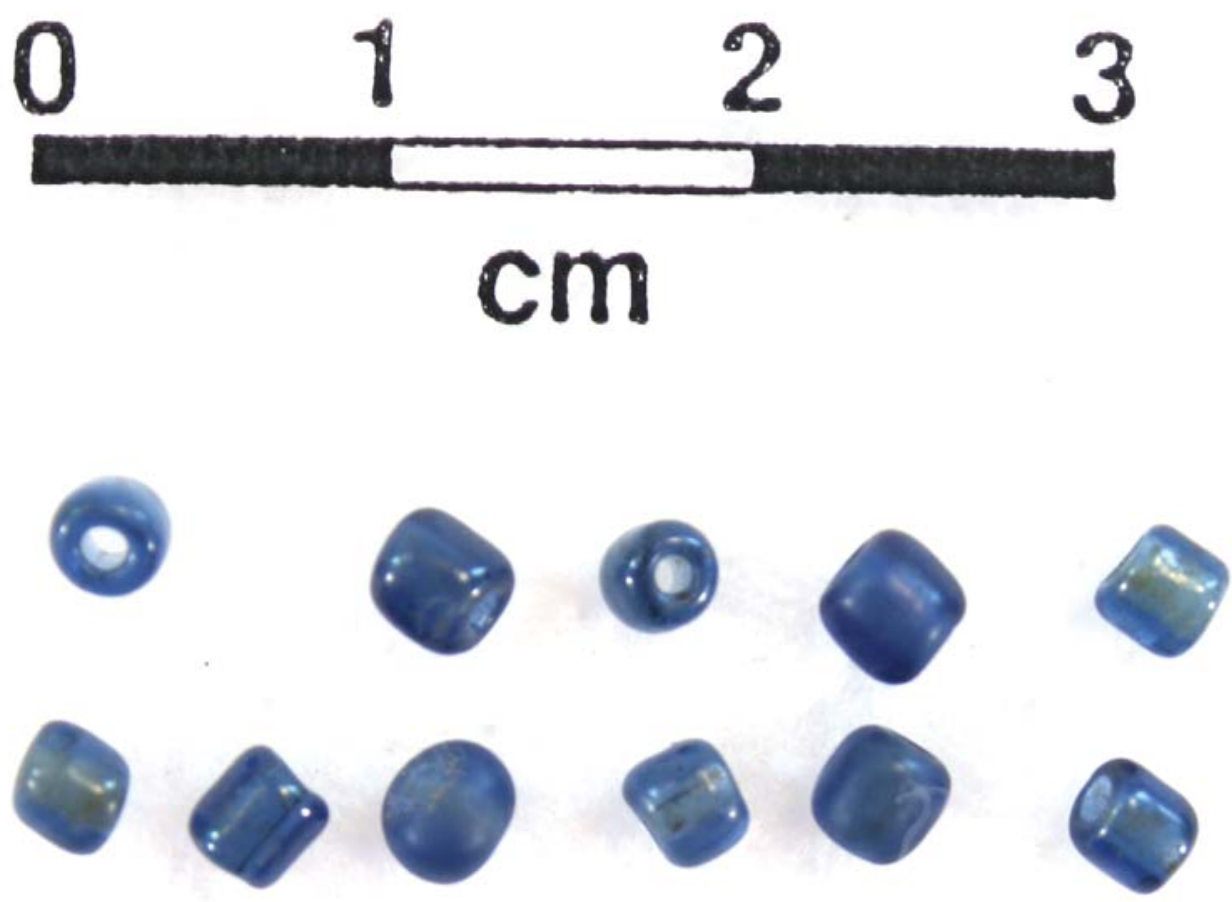

b

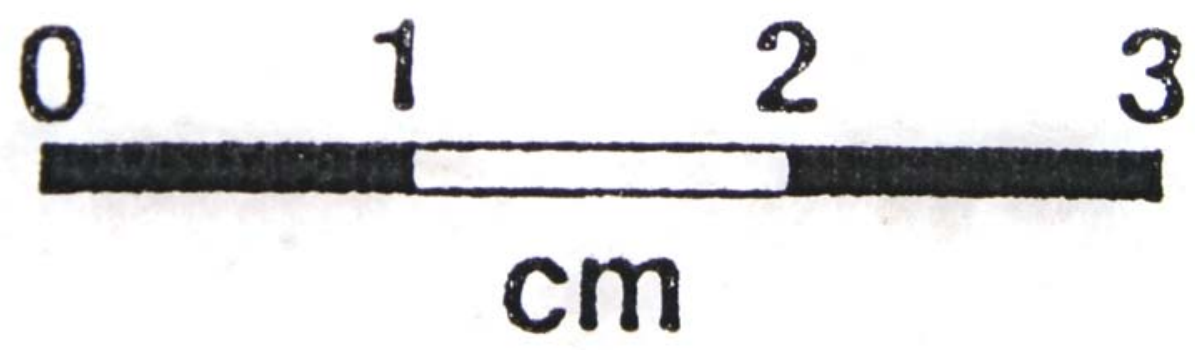

Figure 4. Glass bead groups 4 and 5: a, group 4; b, group 5. 

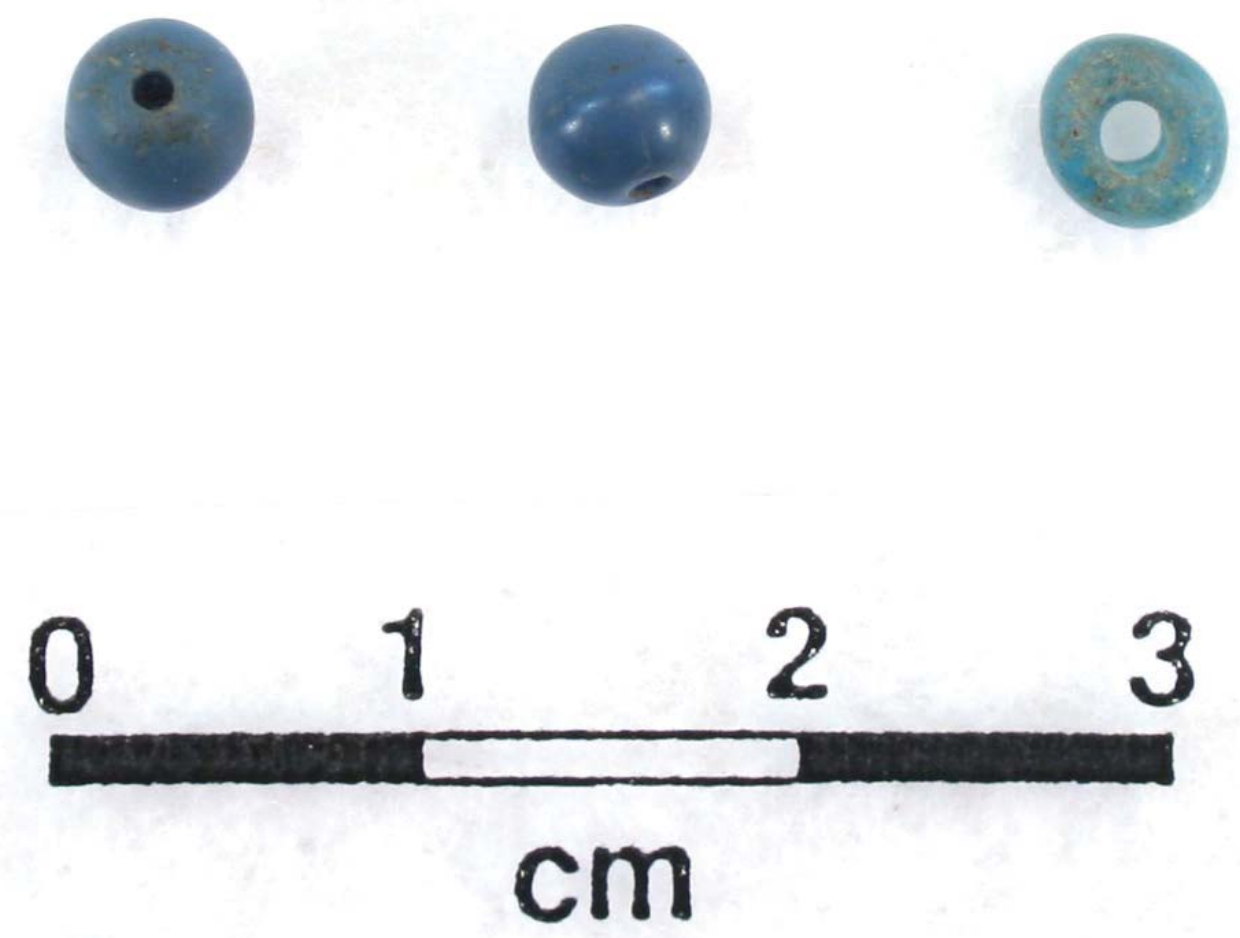

Figure 5. Glass bead group 6.
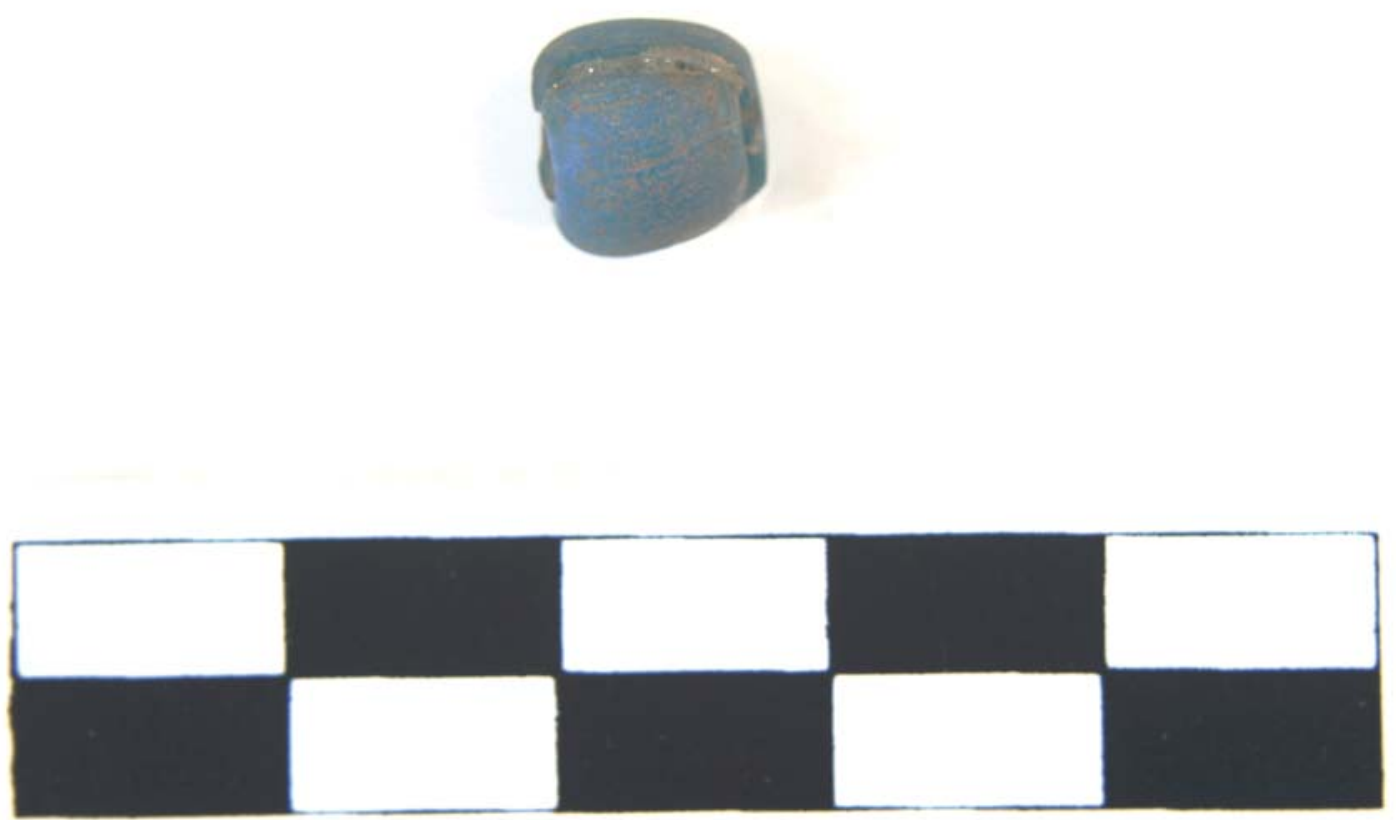

Figure 6. Glass bead group 7. 

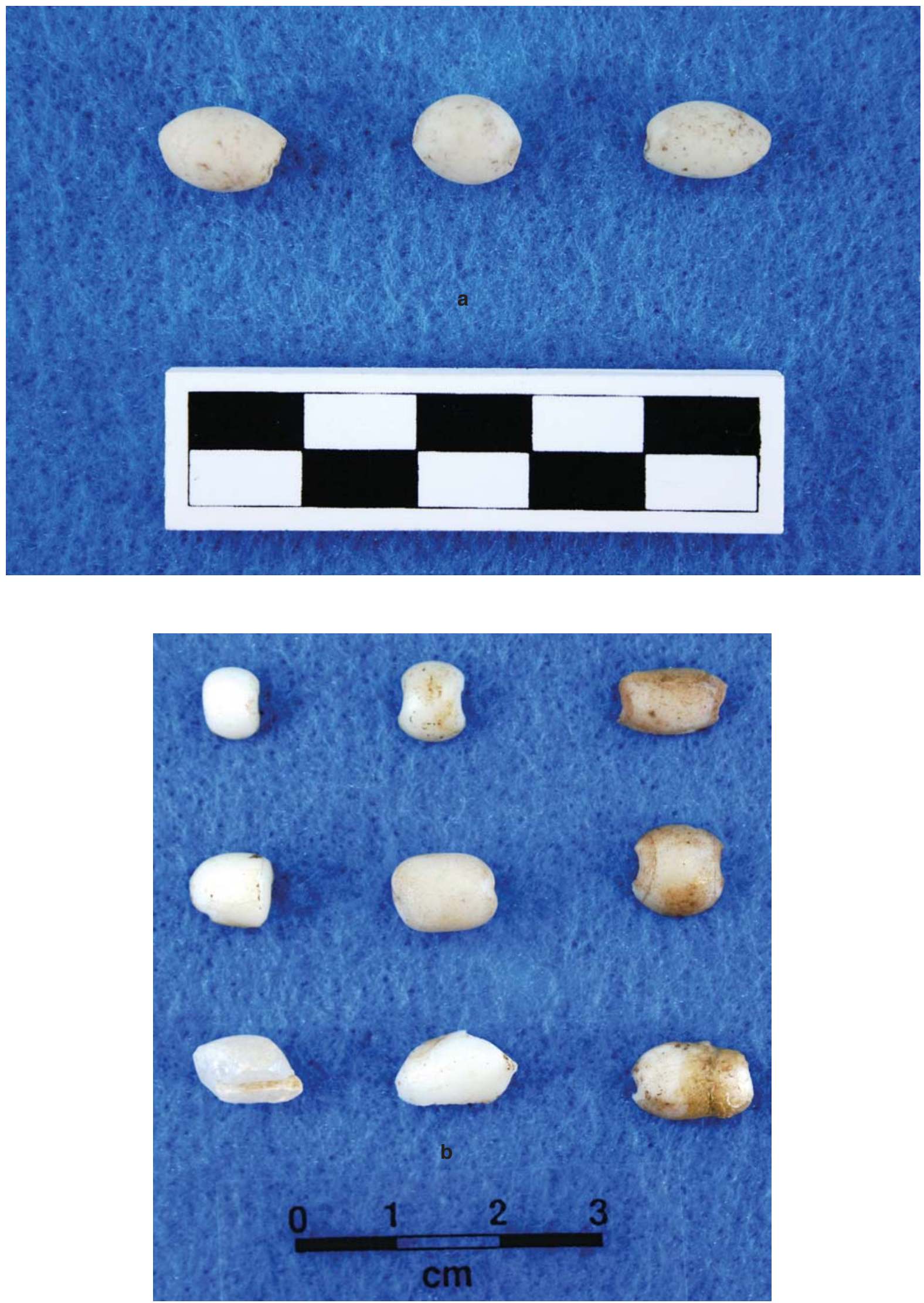

Figure 7. Glass bead groups 8 and 9: a, group 8; b, group 9 . 

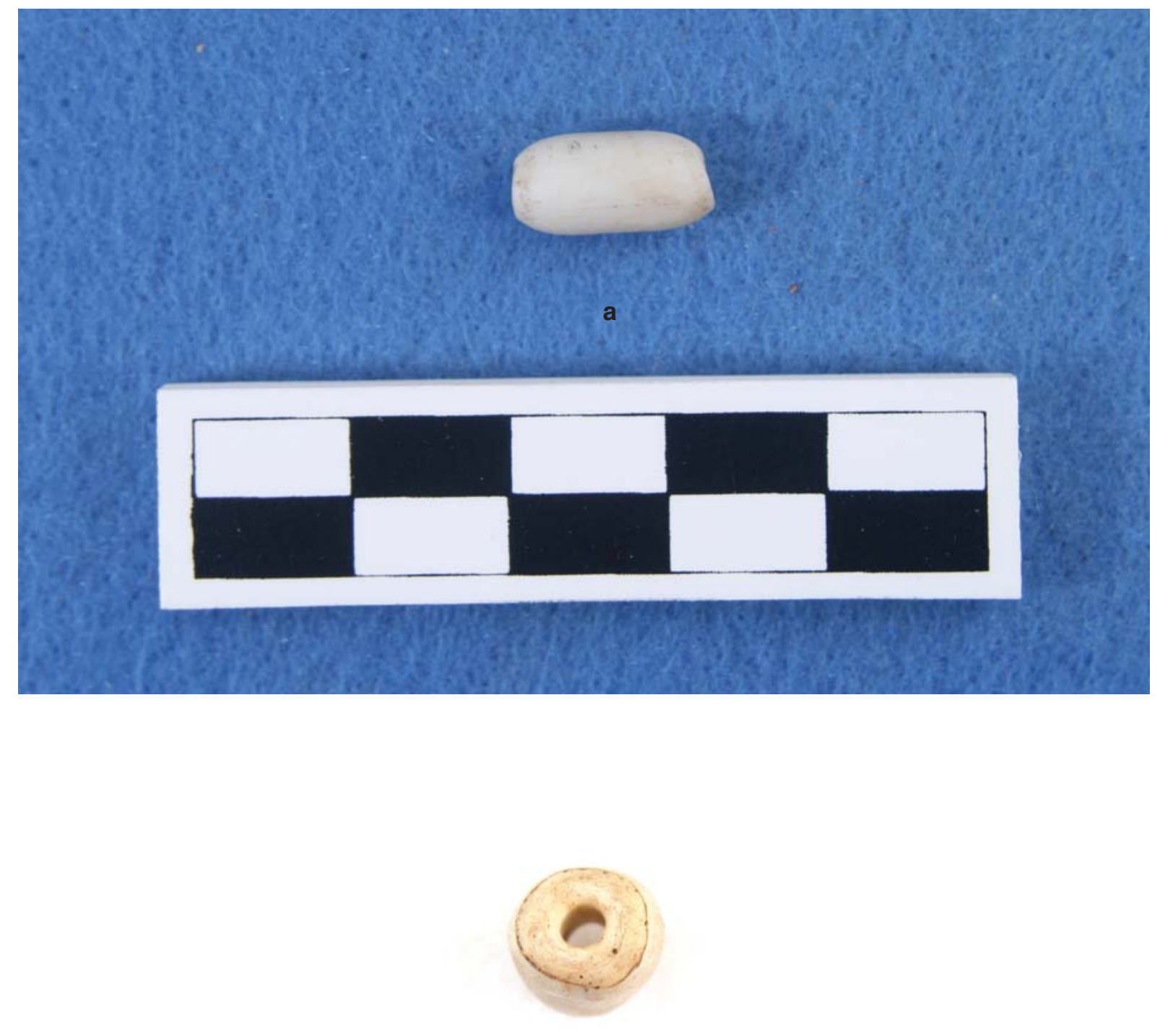

b

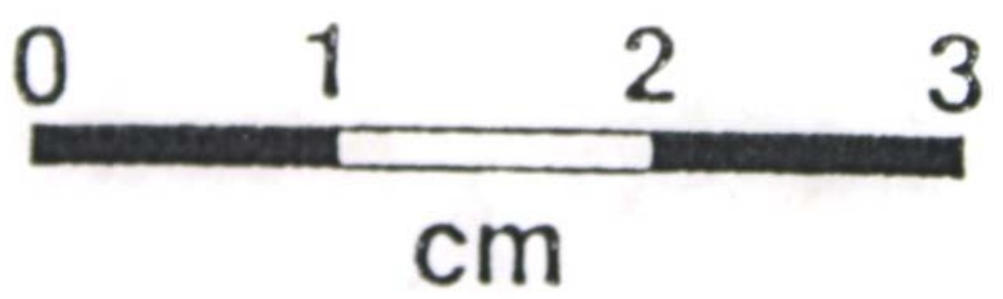

Figure 8. Glass bead groups 10 and 12: a, group 10; b, group 12. 


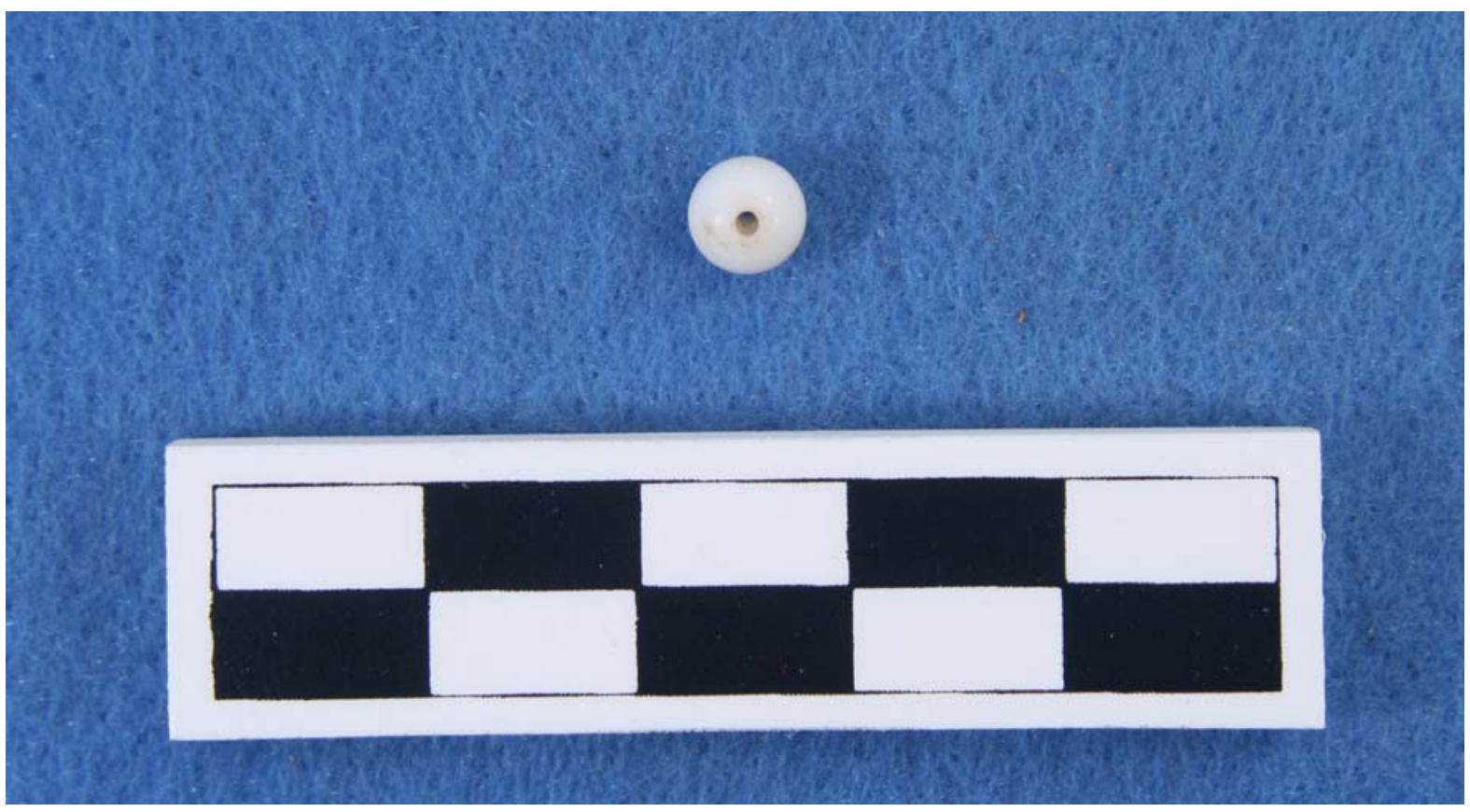

Figure 9. Glass bead group 11.
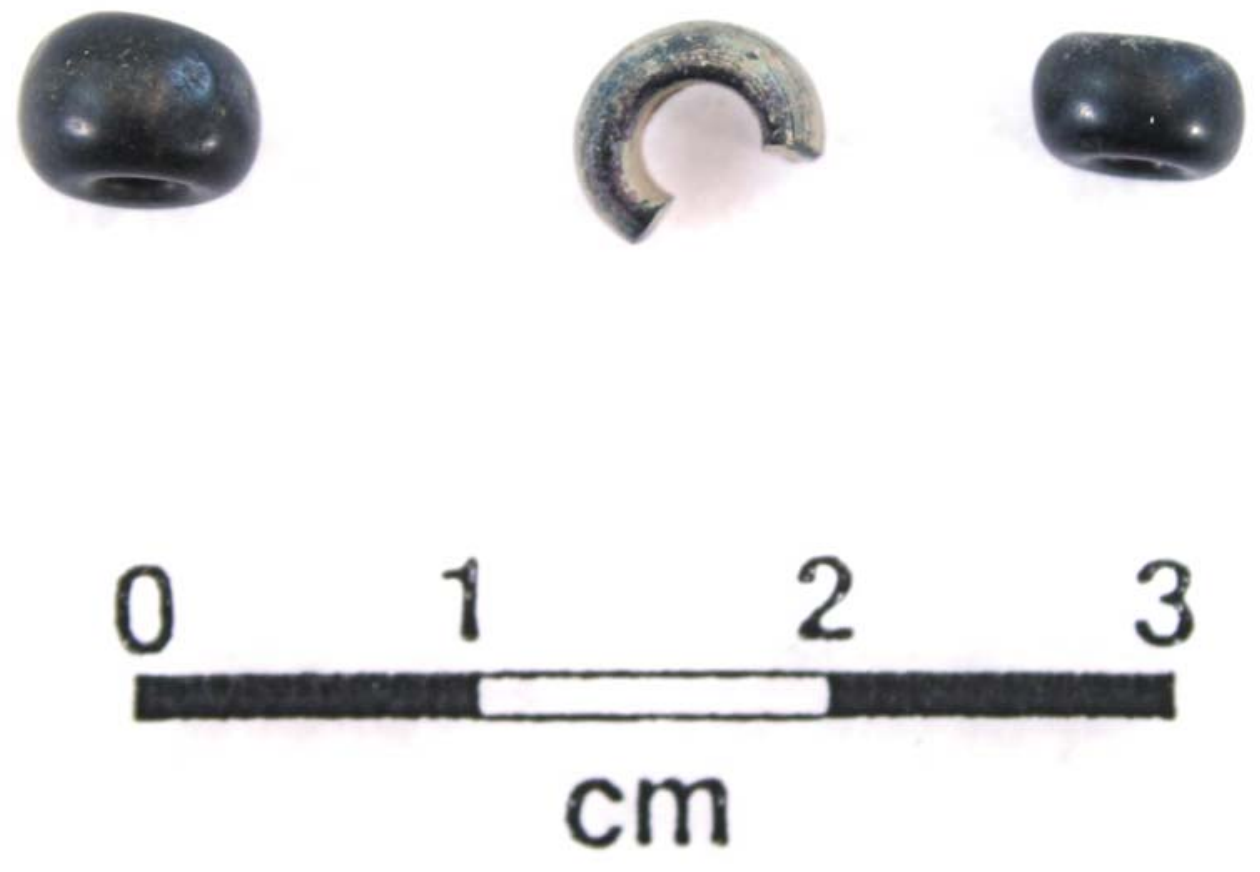

Figure 10. Glass bead group 13. 


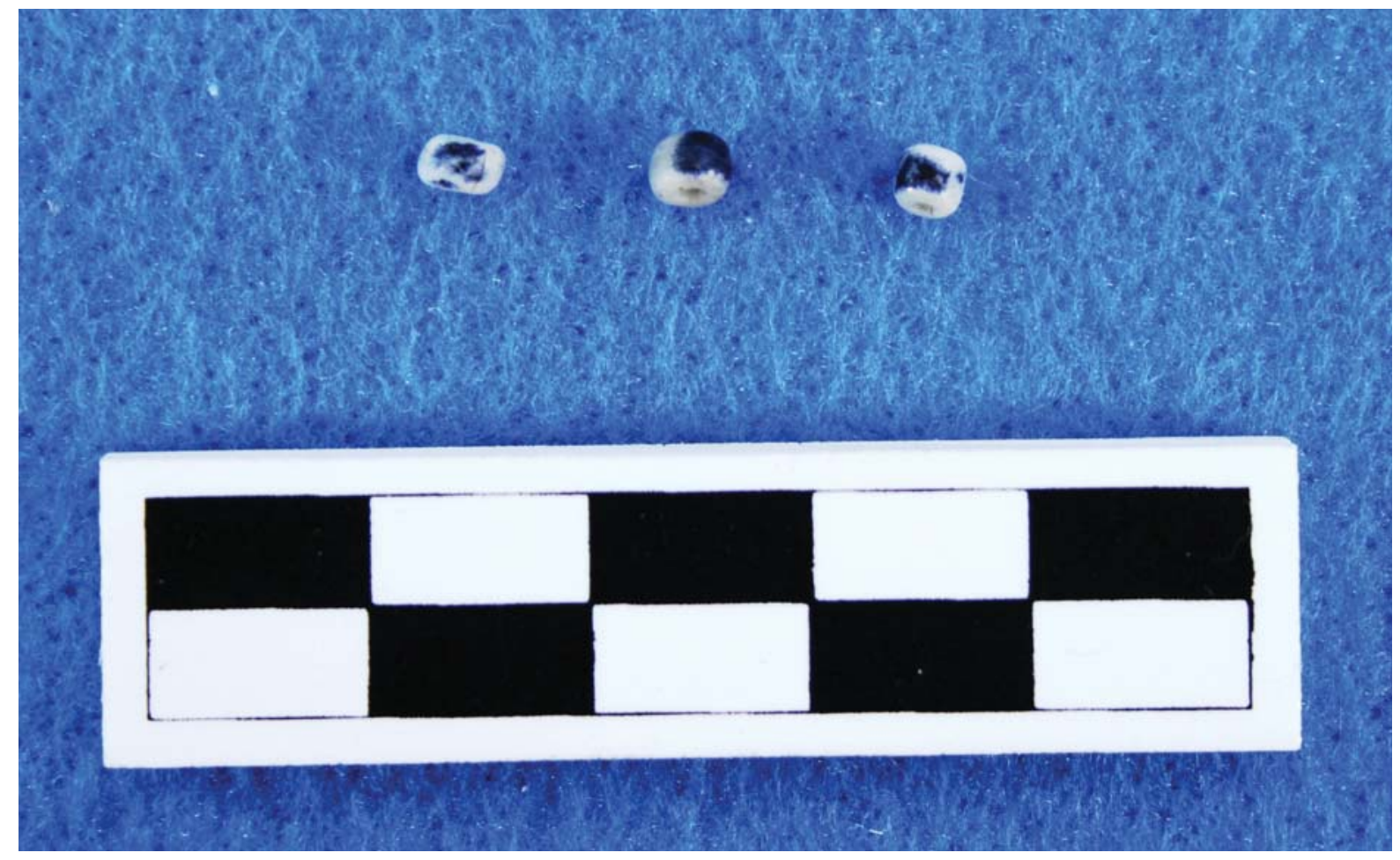

Figure 11. Glass bead group 14.
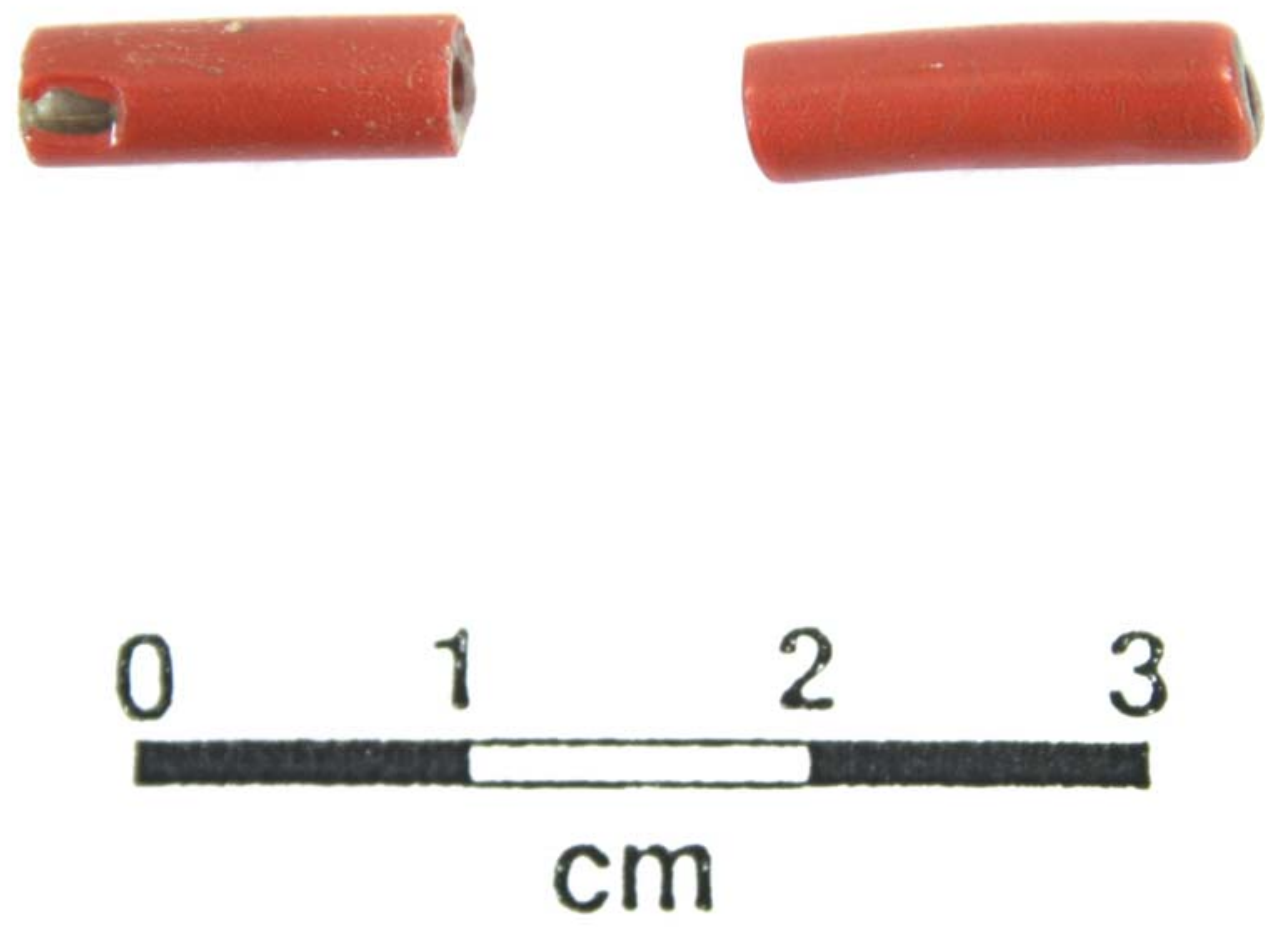

Figure 12. Glass bead group 15. 
62 Journal of Northeast Texas Archaeology 44 (2014)
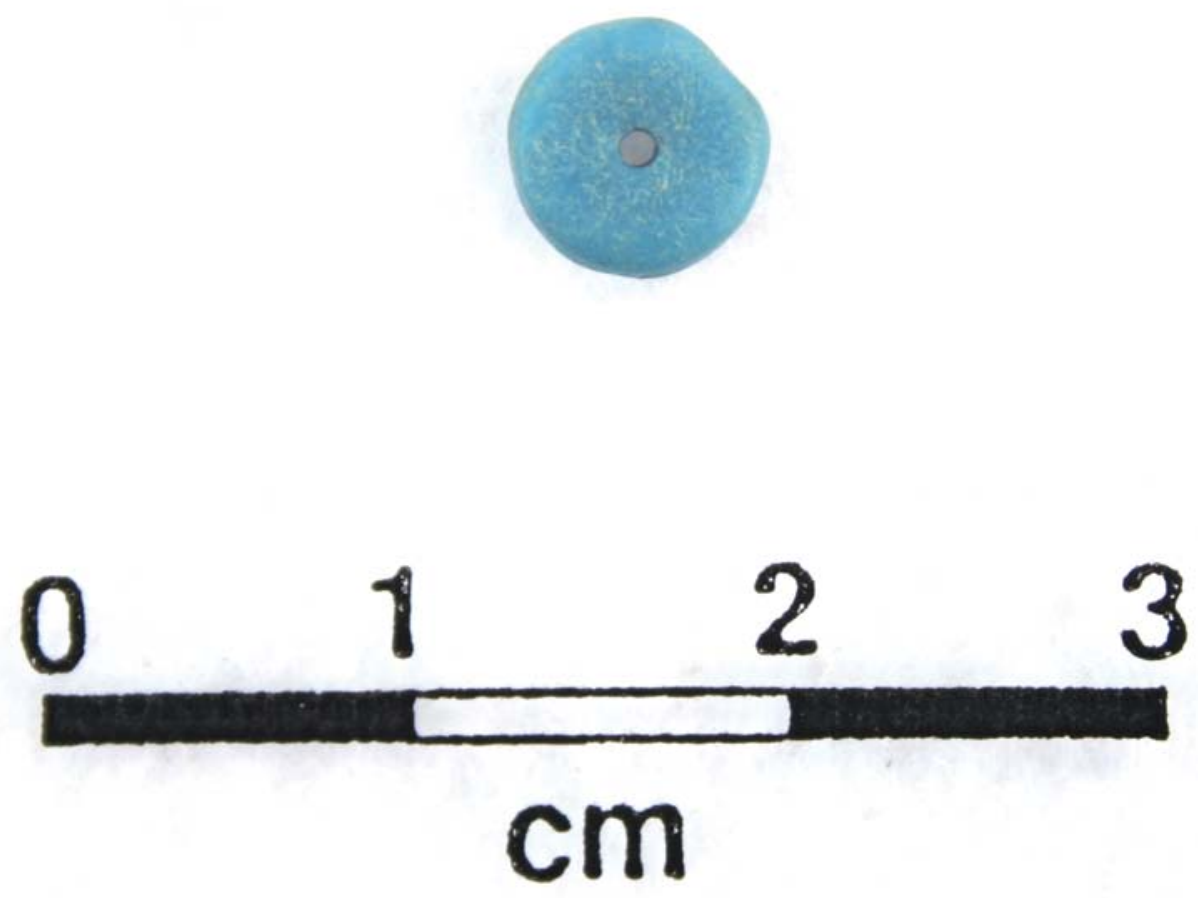

Figure 13. Glass bead group 16.
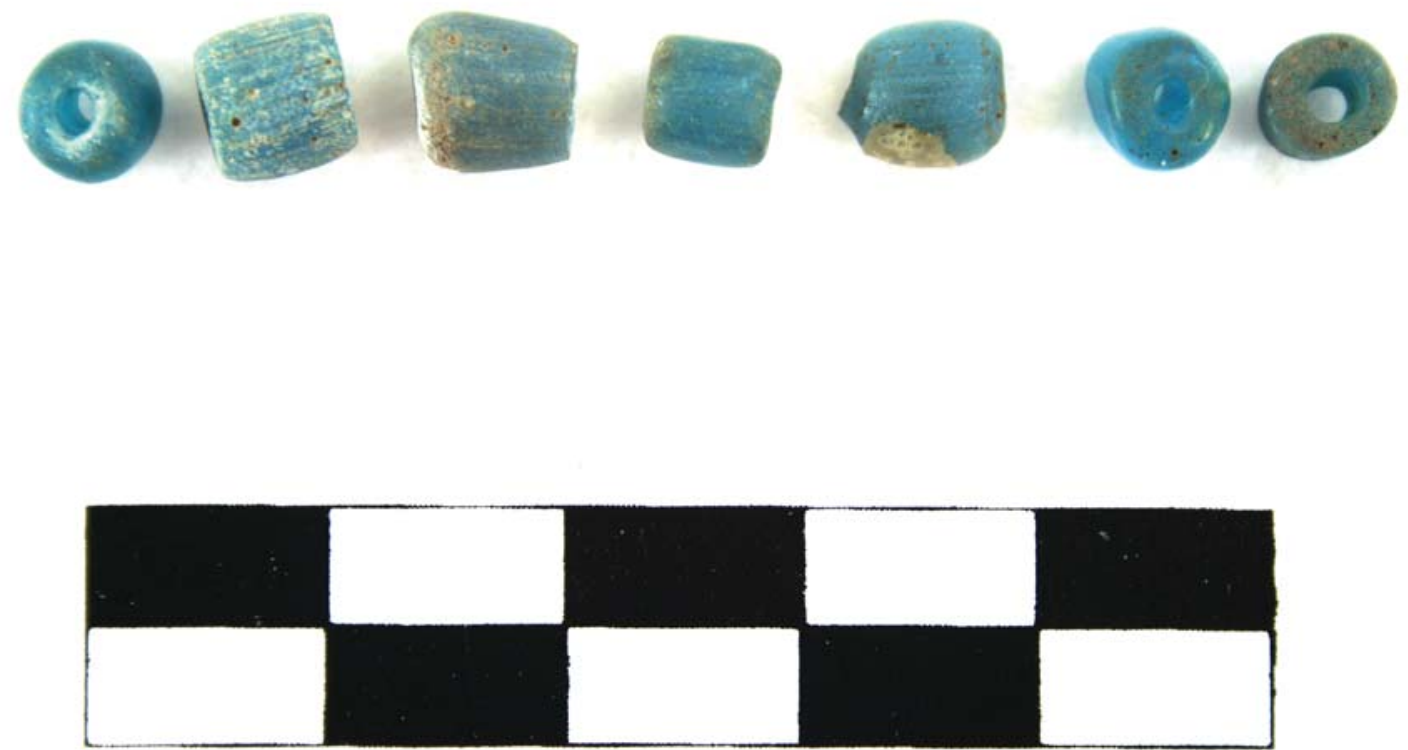

Figure 14. Glass bead group 17. 


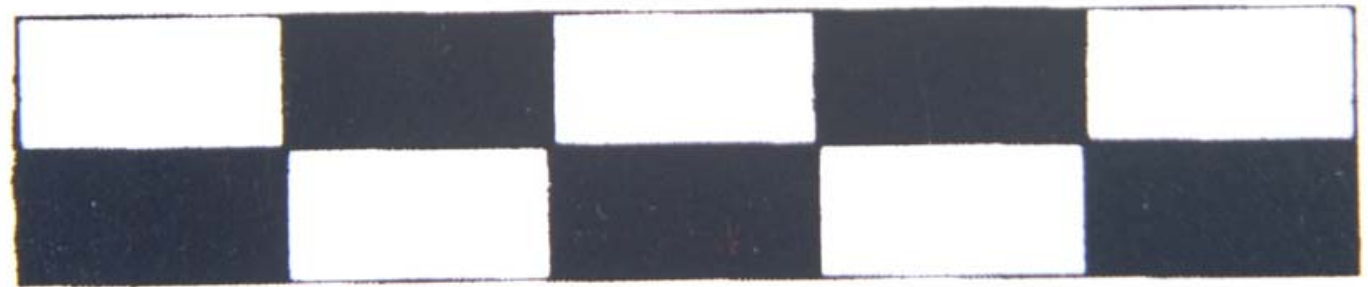

Figure 15. Glass bead group 18.
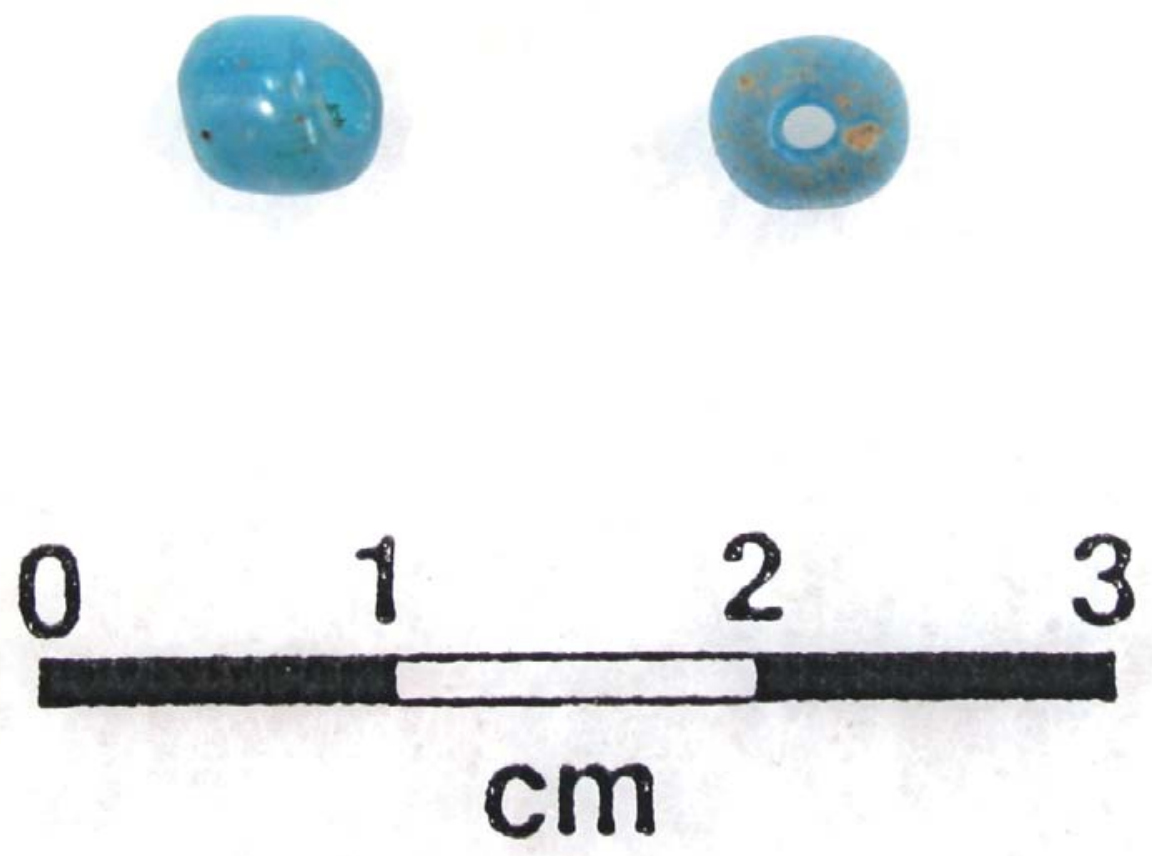

Figure 16. Glass bead group 19. 

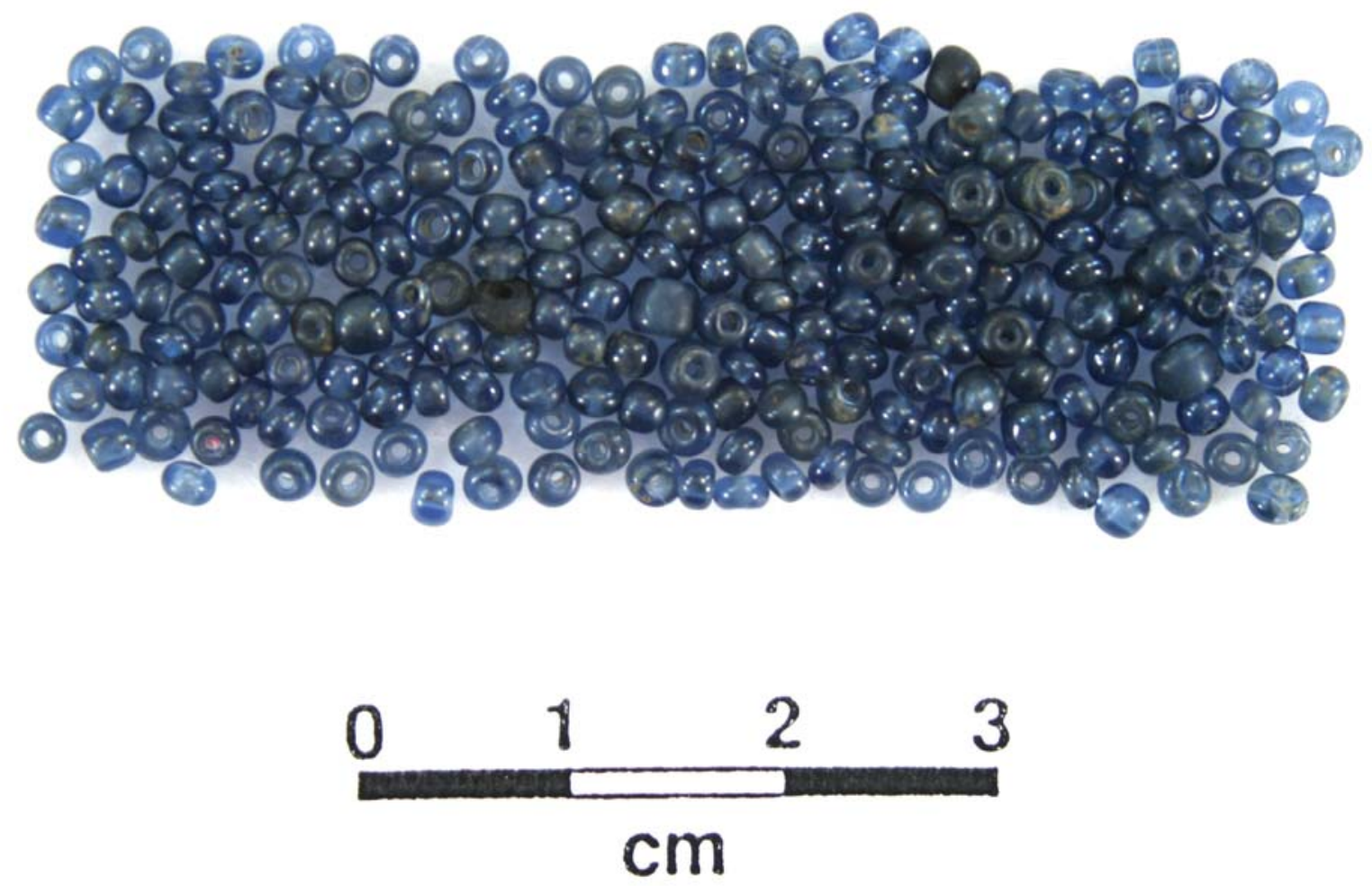

Figure 17. Glass bead group 20.

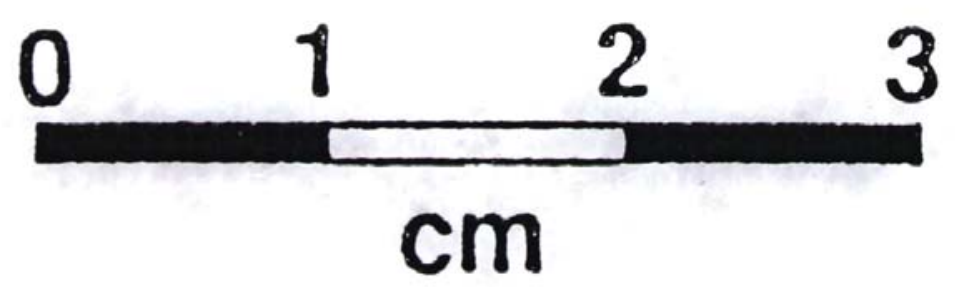

Figure 18. Glass bead group 21. 


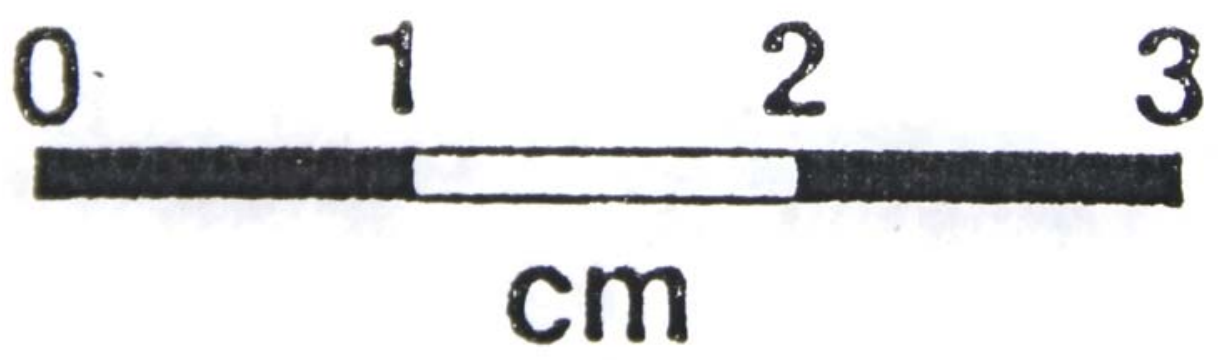

Figure 19. Glass bead group 22.

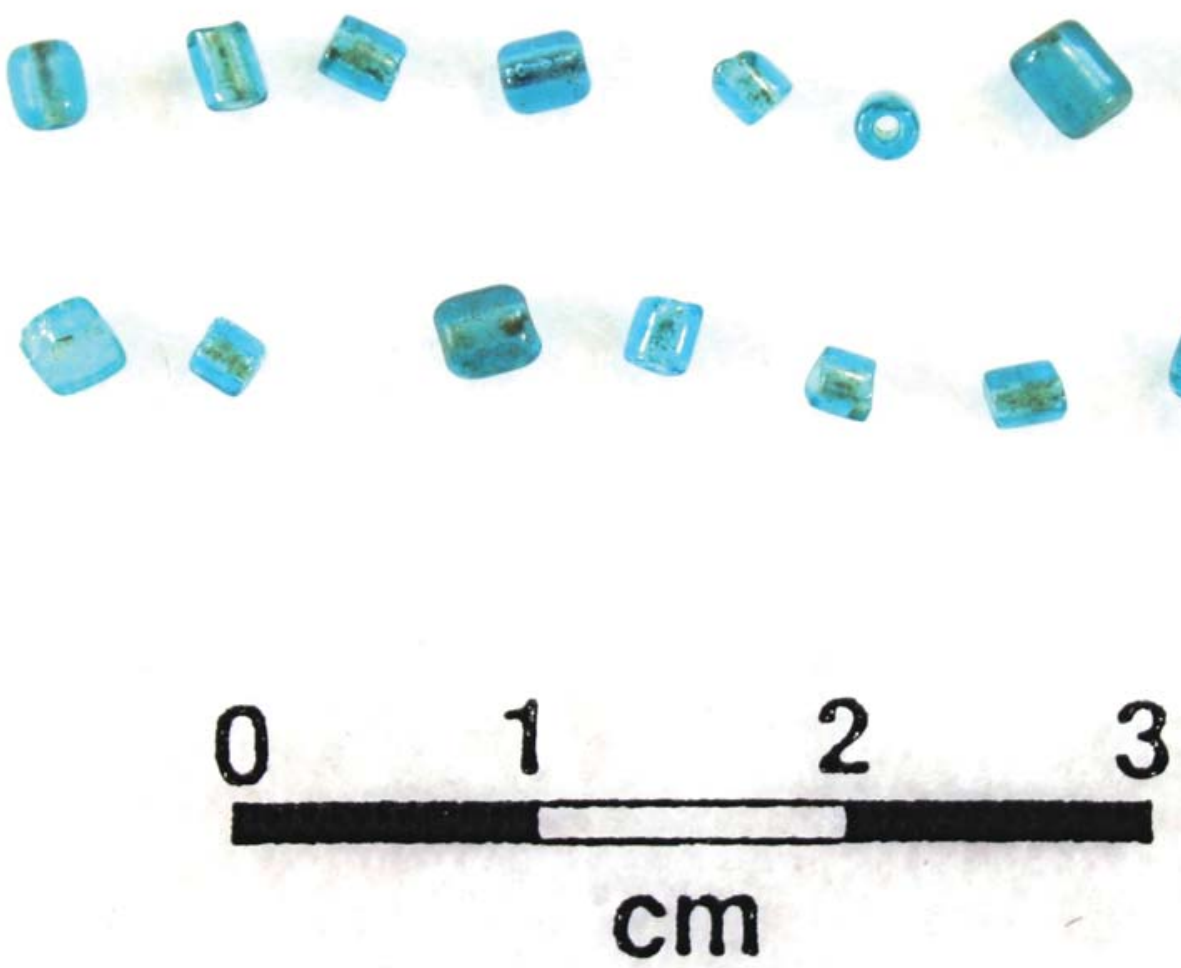

Figure 20. Glass bead group 23. 


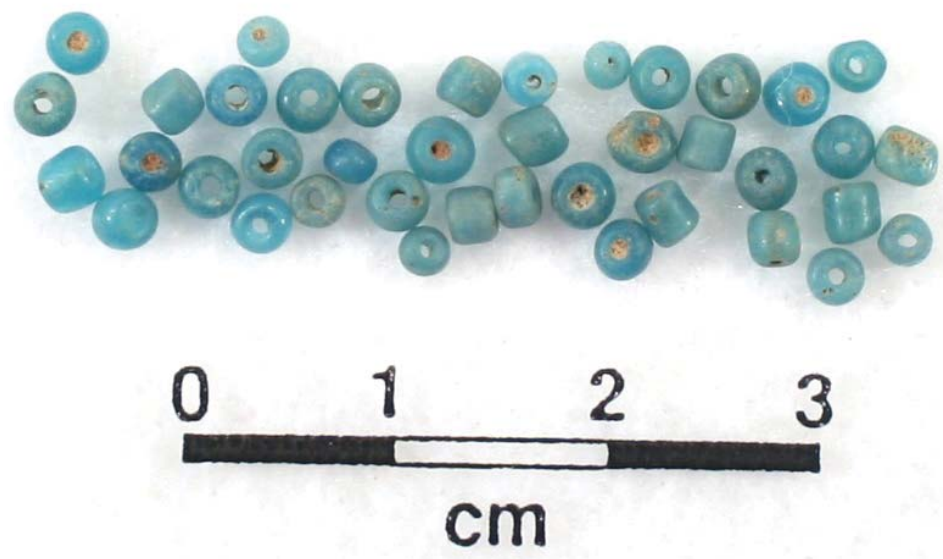

Figure 21. Glass bead group 24.
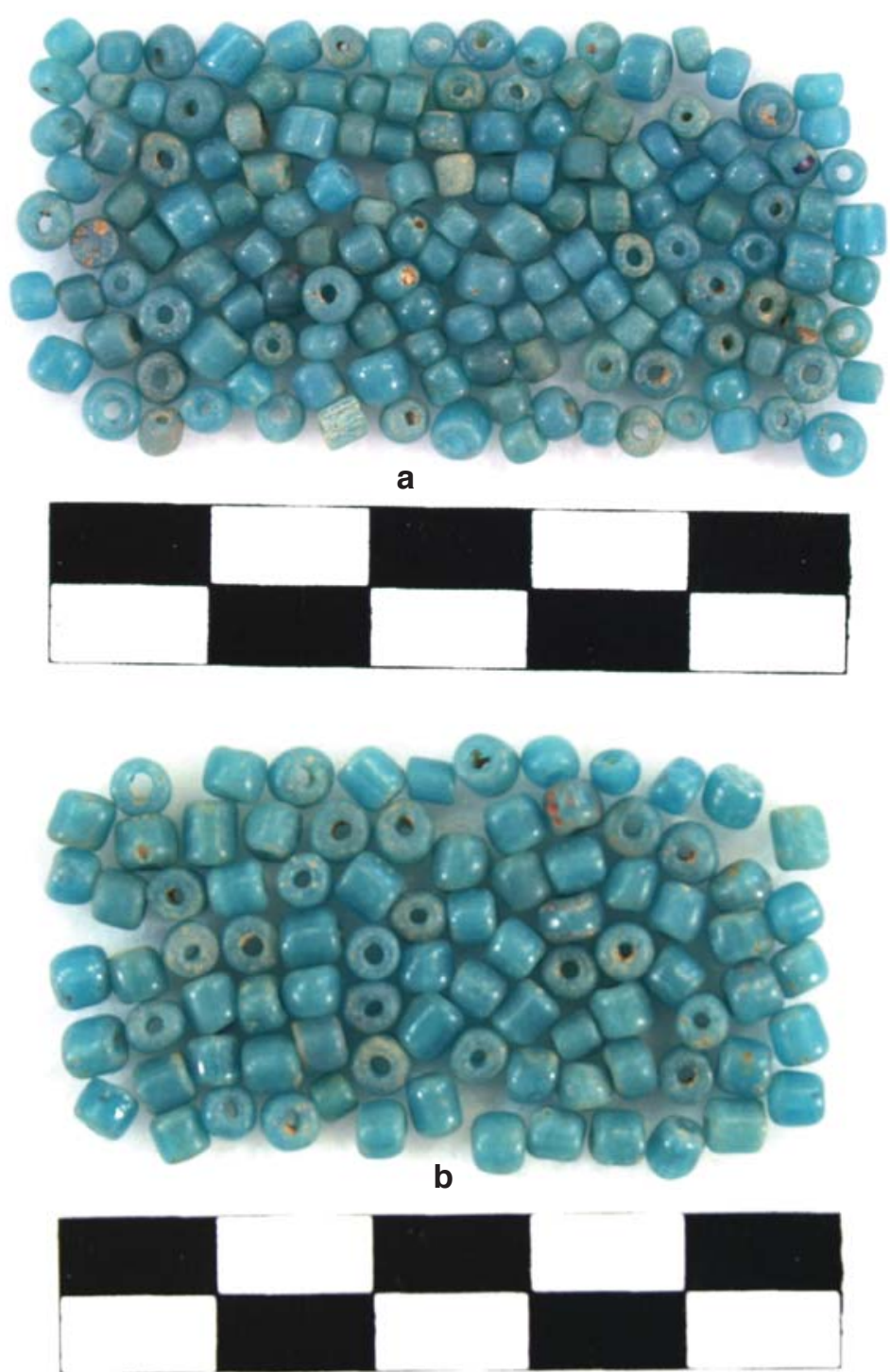

Figure 22. Glass bead groups 25 and 26: a, group 25; b, group 26. 

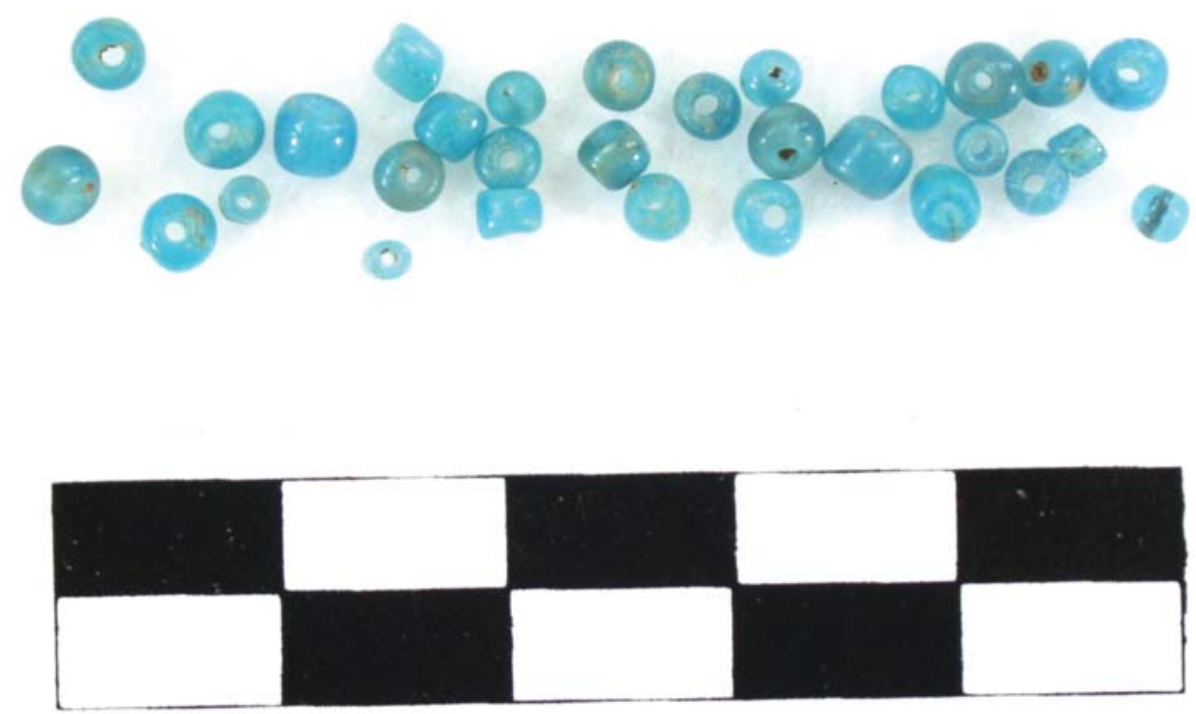

Figure 23. Glass bead group 27.
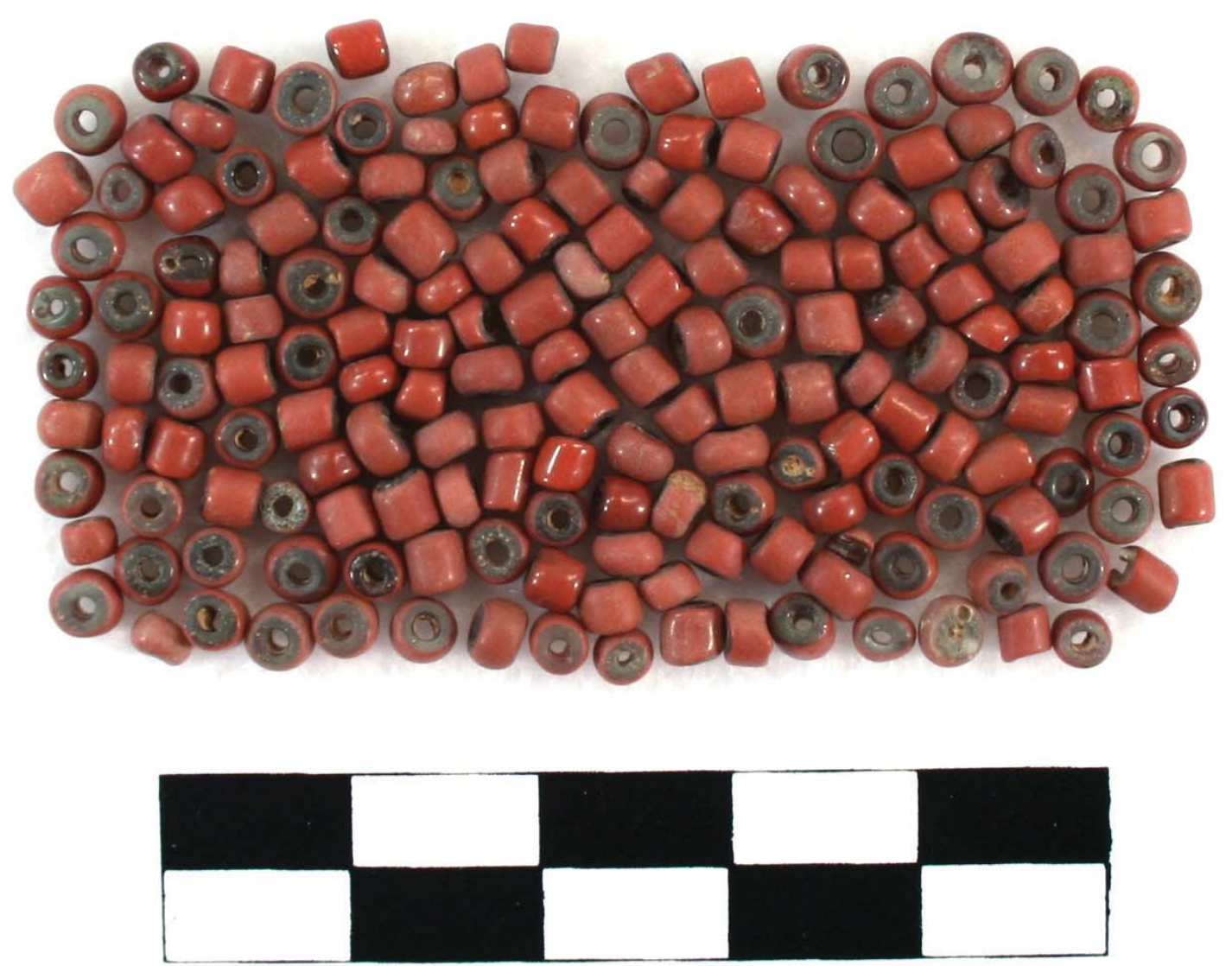

Figure 24. Glass bead group 28. 

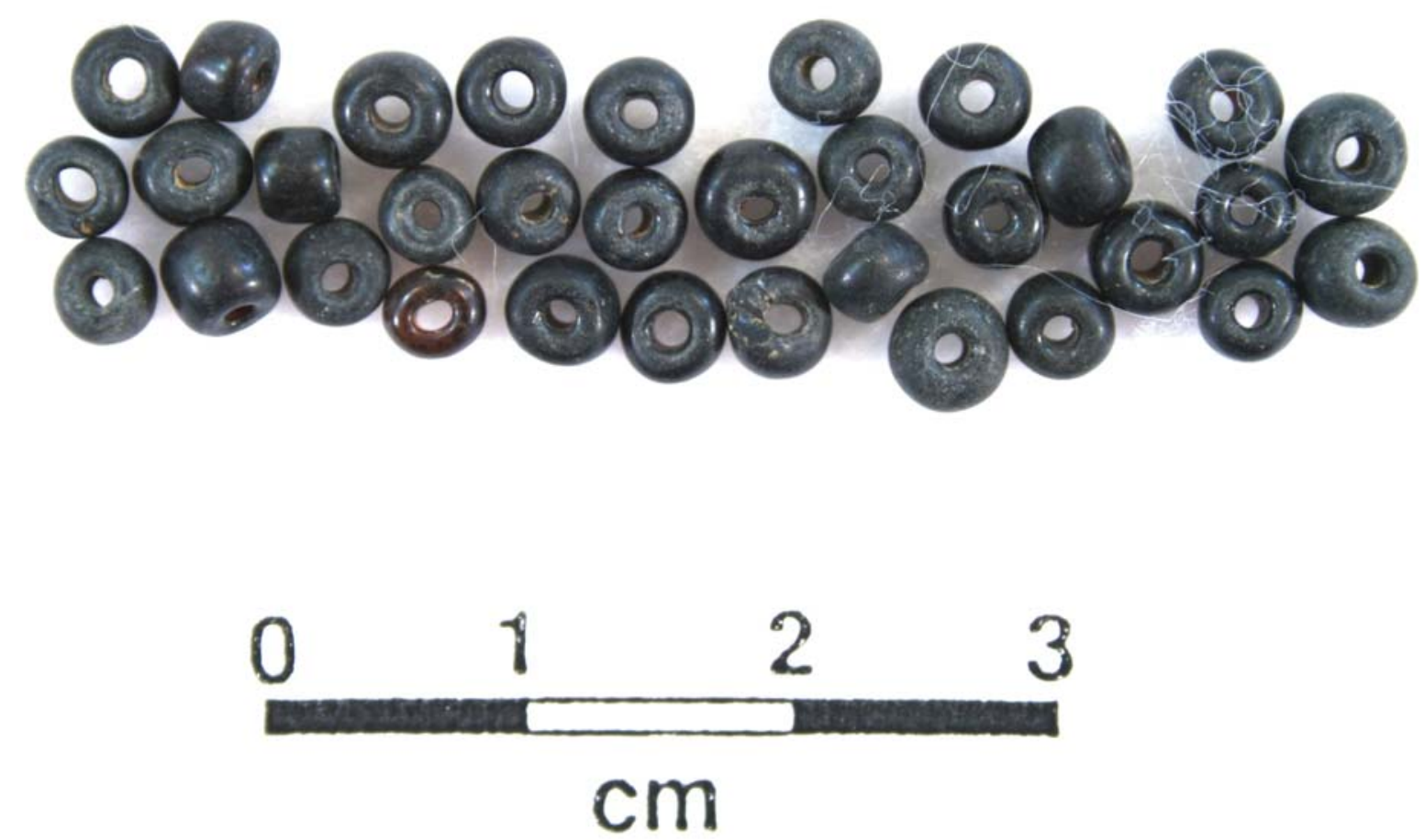

Figure 25. Glass bead group 29.
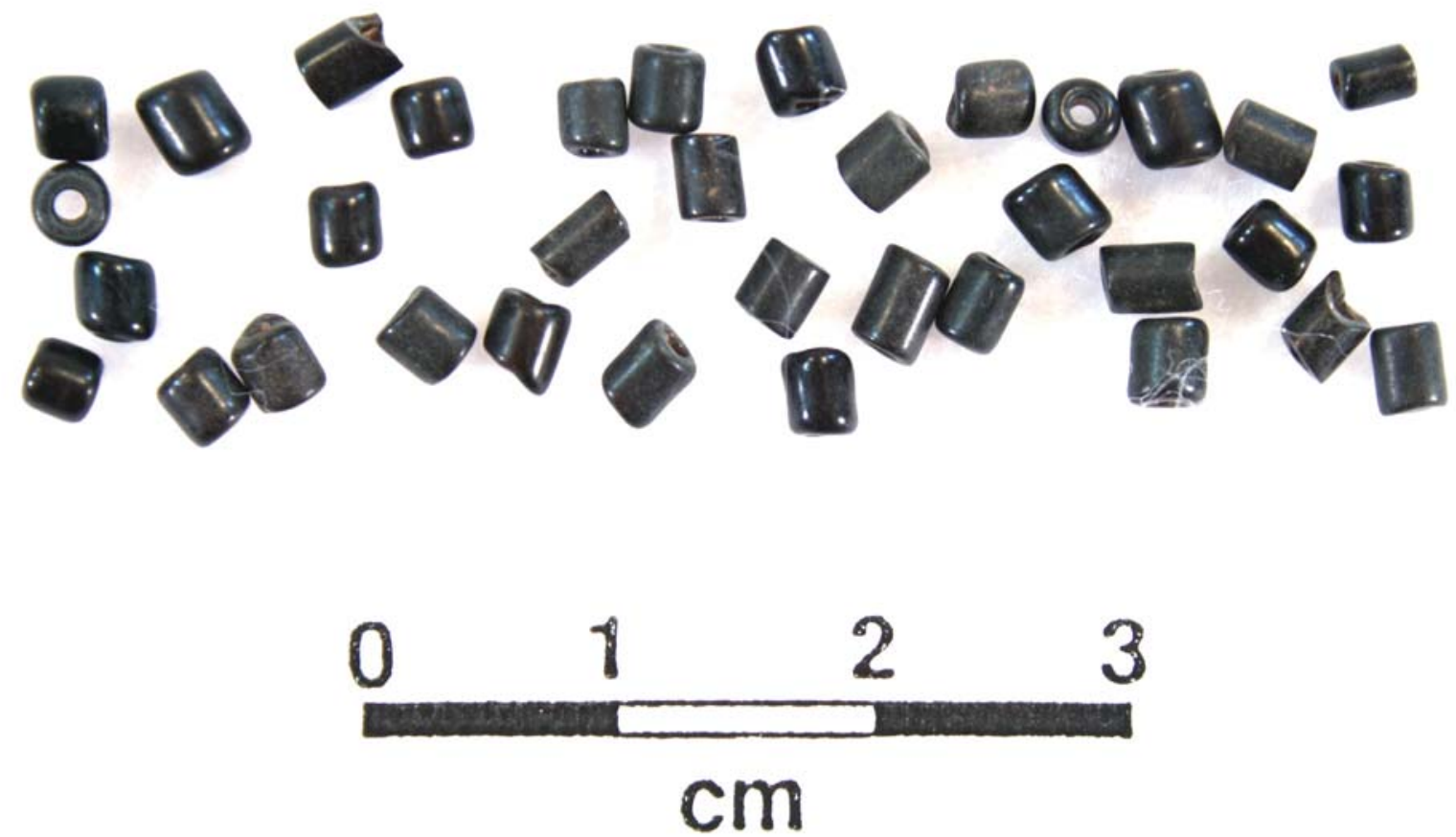

Figure 26. Glass bead group 30 . 


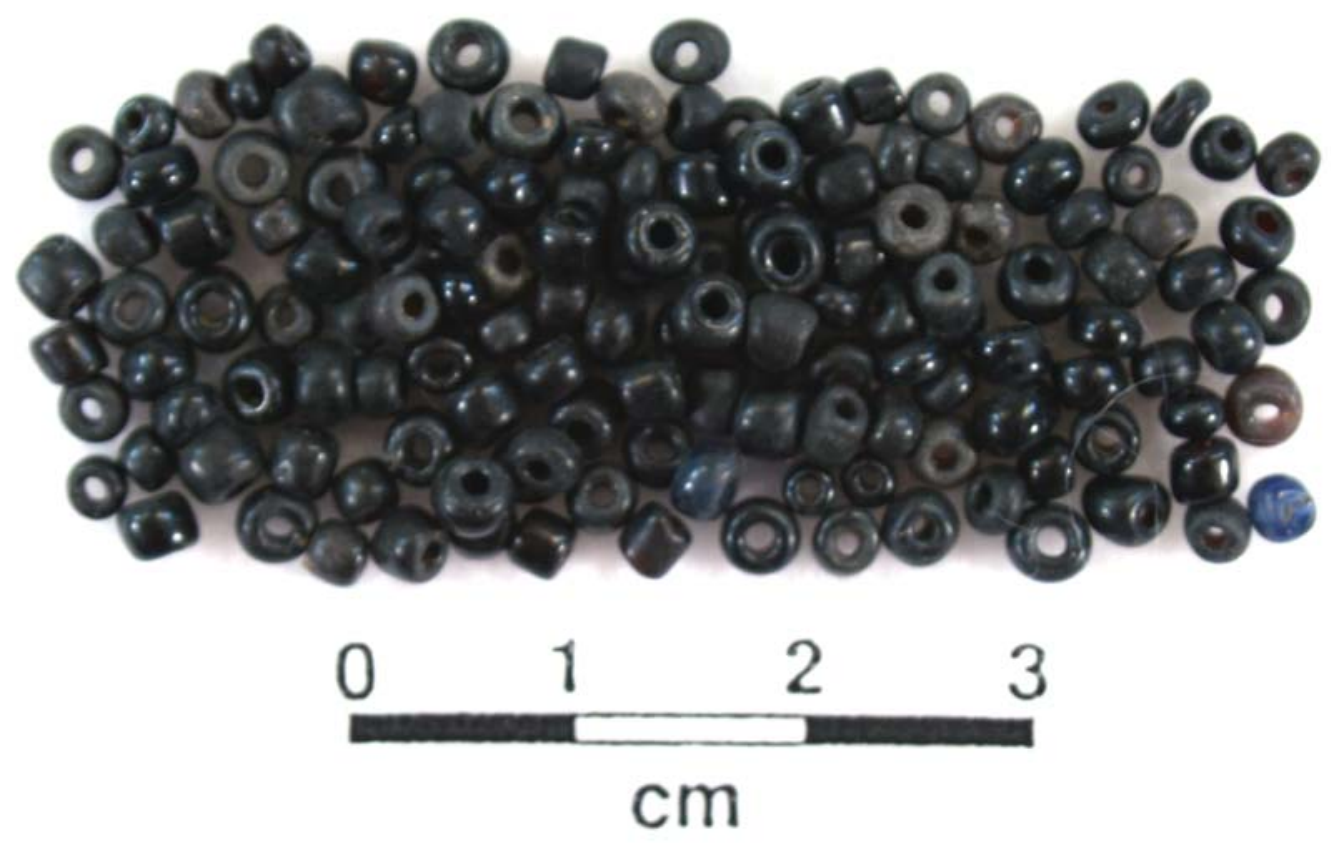

Figure 27. Glass bead group 31. Note that one small Group 3 glass bead was mistakenly included with the photograph of the Group 31 beads.

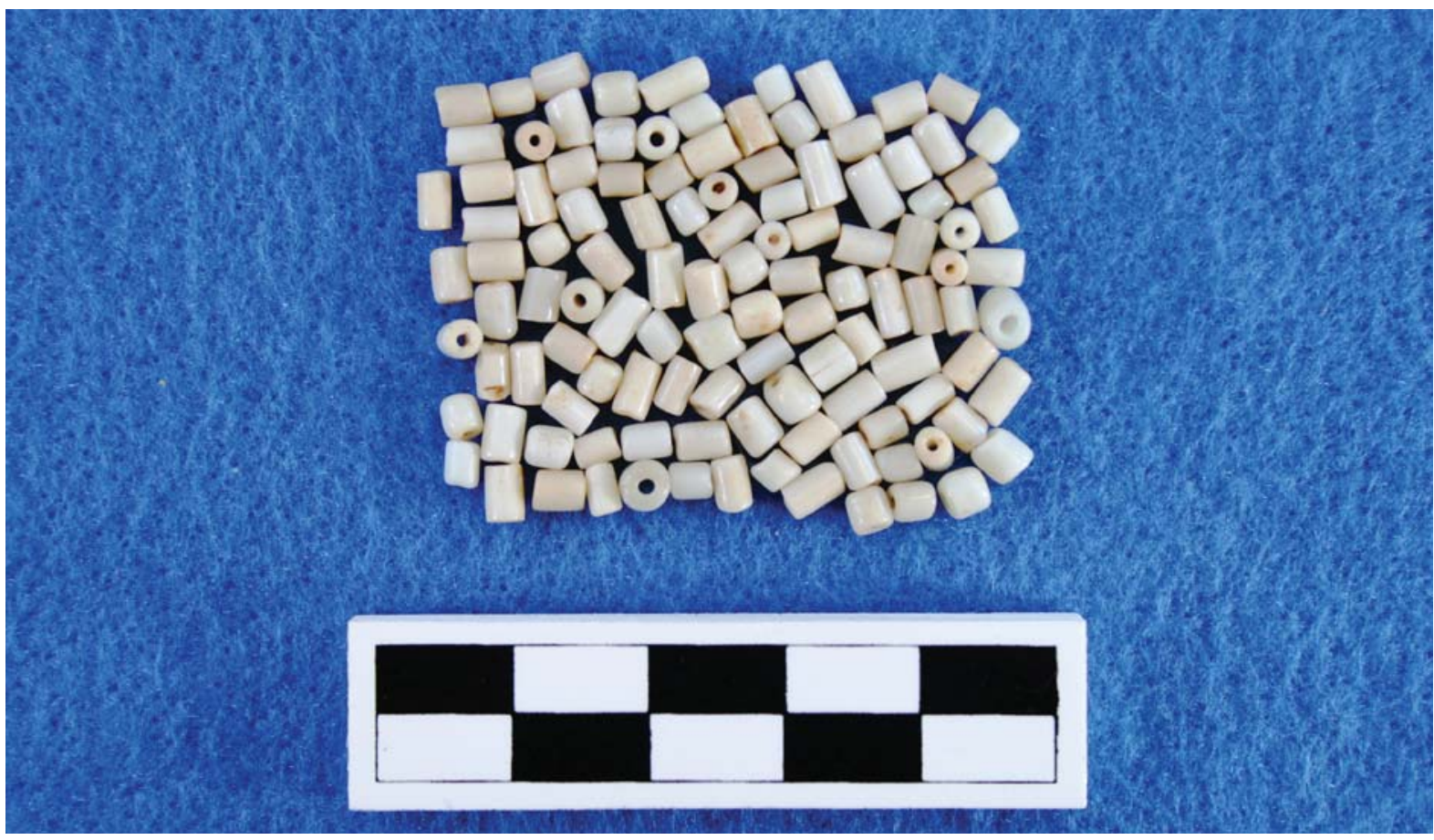

Figure 28. Glass bead group 32. 


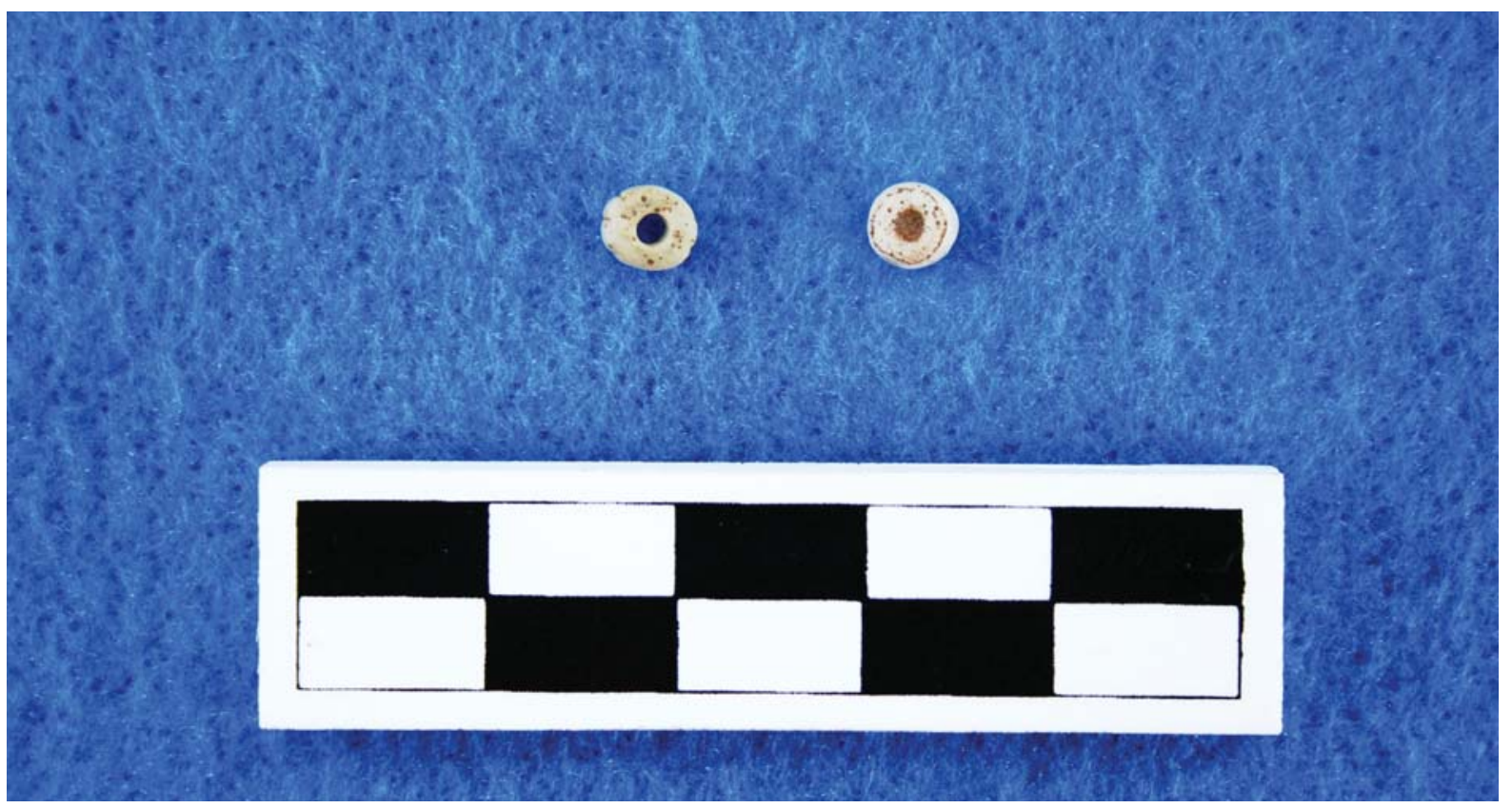

Figure 29. Glass bead group 33.

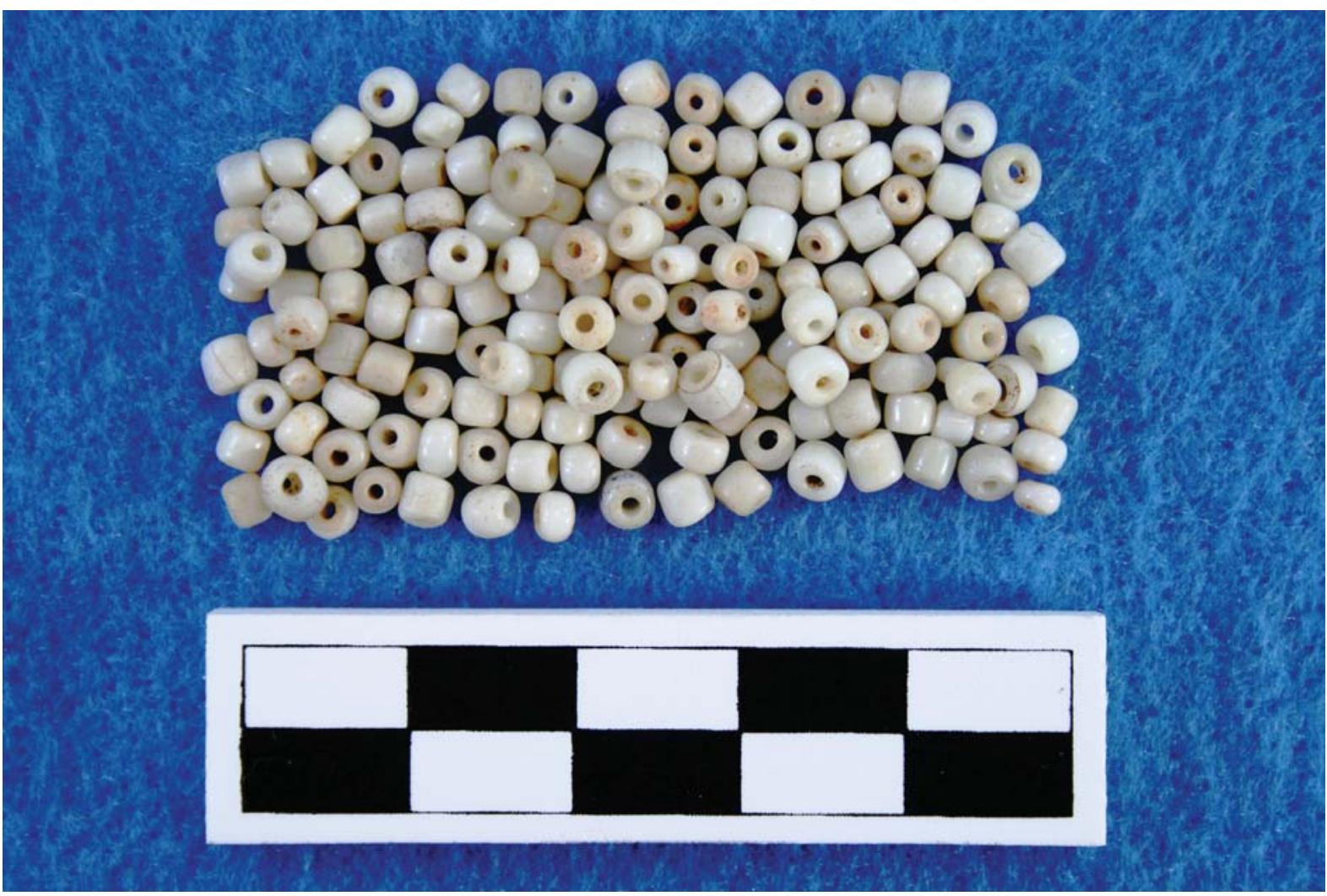

Figure 30. Glass bead group 34 . 
The glass beads from the Kinsloe focus sites are also classified following the widely-employed Kidd and Kidd (1970:Tables 1, 2, 4-5) bead system. Only the three Group 14 beads (see Table 4 and Figure 11) could not be classified using the Kidd and Kidd (1970) bead classes and types (Table 5).

Table 5. Beads from the Kinsloe focus classified following Kidd and Kidd (1970).

\begin{tabular}{llrr}
\hline Bead Type & Description & No. & $\%$ \\
\hline Tubular & & & \\
Ia2 & Black, opaque & 35 & 0.4 \\
Ia5 & White, opaque & 135 & 1.7 \\
Ia13 & Aqua blue, translucent & 33 & 0.4 \\
Ia15 & Brite Blue, translucent & 17 & 0.2 \\
Ia16 & Blue, opaque & 7 & 0.1 \\
Ia18 & Ultramarine, clear & 241 & 0.2 \\
& Subtotal, Class I & & 3.0
\end{tabular}

\section{Rounded}

\begin{tabular}{llrr} 
IIa6 & Black, opaque, round & 1036 & 13.1 \\
IIa13 & White, opaque, round & 4433 & 55.9 \\
IIa15 & White, opaque, oval & 13 & 0.2 \\
IIa20 & Cinnamon, opaque, round & 1 & Trace \\
IIa33 & Lt. Aqua Blue, clear, round & 3 & Trace \\
IIa36 & Aqua Blue, opaque, round & 91 & 1.2 \\
IIa40 & Robin's Egg Blue, opaque, round & 843 & 10.6 \\
IIa44 & Cerulean Blue, clear, round & 1 & Trace \\
IIa54 & Ultramarine, clear, round & 1 & Trace \\
IIb23 & White with four black stripes, opaque, round & 1 & Trace \\
Unidentified & - & 3 & Trace \\
& Subtotal, Class II & 6426 & 81.2 \\
Tubular, Multi-Layered & & \\
IIIa1 & Red outside layer, black core, opaque & 2 & Trace \\
\multicolumn{2}{l}{ Rounded, Multi-Layered } & & 100.0 \\
Iva1 & Red outside layer, black core, opaque, round & 1257 & \\
\hline
\end{tabular}

This classification indicates that the Class II rounded beads comprise $81.2 \%$ of the bead sample from the Kinsloe focus sites, in particular the white, black, and Robin's Egg blue beads (see Table 5). Class IV Cornaline d'Aleppo rounded multi-layered round beads are the second most common bead class in the Kinsloe focus bead assemblage; this class of beads is characteristic of many $18^{\text {th }}$ century Texas Caddo sites, more so than many other historic Native American sites in the southeastern U.S. The tubular bead classes I and III represent only $3 \%$ of the beads in the sample, including white, blue, and black tubular beads, and only two Cornaline d'Aleppo tubular multi-layered beads (see Table 5). 


\section{SUMMARY AND CONCLUSIONS}

There is a large sample ( $\mathrm{n}=7926)$ of European glass beads - likely made in either Venice or Amsterdam - from Historic Caddo Kinsloe focus sites in the mid-Sabine River basin of the East Texas Pineywoods. Because specific site provenience for these beads has been lost over the years since they were collected from Kinsloe focus burials excavated by Buddy C. Jones, our analysis of these glass beads must be at the overall assemblage level. The assemblage of Kinsloe focus beads features small (less than $4.0 \mathrm{~mm}$ in diameter) round beads of white, black, red (Cornaline d'Aleppo), and blue colors, as well as a few tubular beads of the same colors. The very high proportion of small beads suggests that the Kinsloe focus assemblage dates primarily from after ca. 1740 to the early $19^{\text {th }}$ century, given trends in bead sizes. By the early $19^{\text {th }}$ century, small drawn beads tended to comprise more than $90-95 \%$ of the beads from sites in Texas and Northwest Louisiana (Perttula et al. 2010:Table 5).

We also made color comparisons between the Kinsloe focus bead assemblage and other large bead assemblages from Caddo sites in East Texas and Northwest Louisiana, based on summaries in Avery (2008:Table 1). The very high percentages of white beads in these sites would seem to indicate that differences in the proportions of bead colors on Kinsloe focus sites, and on beads of other Caddo tribes, are probably evidence for particular Nadaco Caddo color and size preferences that were accommodated for a considerable time by different European traders

\section{ACKNOWLEDGMENTS}

We first thank Patti Haskins of Gregg County Historical Museum for facilitating the study of the glass beads in the Buddy Jones collection at the museum. Bo Nelson took the photographs of the different bead groups.

\section{REFERENCES CITED}

Avery, G.

2008 Seed Bead Color Patterns from Colonial Period Sites in Texas and Louisiana. Journal of Northeast Texas Archaeology 28:57-63.

Fields, R. C. and E. F. Gadus (editors)

2012 Archeology of the Nadaco Caddo: The View from the Pine Tree Mound Site (41HS15), Harrison County, Texas. 2 Vols. Reports of Investigations No. 164. Prewitt and Associates, Inc., Austin.

Jones, B. C.

1968 The Kinsloe Focus: A Study of Seven Historic Caddoan Sites in Northeast Texas. Master's thesis, Department of Anthropology, University of Oklahoma, Norman.

Kidd, K. E. and M. A. Kidd

1970 A Classification System for Glass Beads for the Use of Field Archaeologists. In Occasional Papers in Archaeology and History No. 1, pp. 45-89. National Historic Sites Service, National and Historic Parks Branch, Department of Indian Affairs and Northern Development, Ottawa.

Perttula, T. K.

1992 "The Caddo Nation": Archaeological and Ethnohistoric Perspectives. University of Texas Press, Austin.

Perttula, T. K., B. Nelson, and M. Walters

2012 Caddo Archaeology at the Henry Spencer Site (41UR315) in the Little Cypress Creek Basin of East Texas. Special Publication No. 20. Friends of Northeast Texas Archaeology, Pittsburg and Austin. 
Perttula, T. K., B. Nelson, R. L. Cast, and B. Gonzalez

2010 The Clements Site (41CS25): A Late $17^{\text {th }}$ to Early $18^{\text {th }}$-Century Nasoni Caddo Settlement and Cemetery. Anthropological Papers No. 92. American Museum of Natural History, New York.

Perttula, T. K., R. Z. Selden, Jr., and B. Nelson

2013a Documentation of Unassociated Ceramic Vessel Funerary Objects in the Gregg County Historical Museum Collections from Sites in Gregg, Harrison, and Panola Counties in East Texas. Historic Preservation Program, Caddo Nation of Oklahoma, Binger, in press.

Perttula, T. K., B. Nelson, and R. Z. Selden, Jr.

2013b Documentation of Cemeteries and Funerary Offerings from Sites in the Upper Neches River Basin, Anderson, Cherokee, and Smith Counties, Texas. Special Publication No. 26. Friends of Northeast Texas Archaeology, Pittsburg and Austin. 